\title{
IS IT POSSIBLE TO DESIGN ISOTOPIC MASS-DEPENDENT MS-PATCH-CLAMP AND ISOTOPIC MASS-INDEPENDENT ESR-PATCH-CLAMP?
}

\section{Sergey Pankratov}

N.N. Semenov Institute of Chemical Physics, Russian Academy of Sciences, Moscow, Russia

\author{
S. Pankratov \\ 4 Kosygin str., Moscow, Russia 119991 \\ E-mail: pankrater@bk.ru
}

\begin{abstract}
This paper is a comprehensive review of the possibilities of isotopic patch-clamp and isotopic mass-patch-clamp technique development and represents a brief summary of the student's tutorial review by S. Pankratov. We propose to distinguish between the mass-dependent and mass-independent patch-clamp. The main principles introduced here will be developed in details at the second part of this paper.
\end{abstract}

Keywords: mass-dependent isotope effect, mass-independent isotope effect, mass spectrometry, electron spin resonance spectroscopy, electron paramagnetic resonance spectroscopy, (radio)isotope measurements, spin label, patch-clamp. 


\section{Towards the mass-dependent isotopic patch-clamp}

It has just been established that ion channels of the living cell can be studied using nuclear magnetic resonance (NMR) spectroscopy with isotope labeling (Abarca-Heideman, 2013) (for example, a number of simple bacterial channels, such as the potassium channel (Bhate, 2013), can be labeled for NMR). It is now evident that channelome (i.e. a complete set of the membrane ion channels in a biological tissue (Hoffert, 2009; Barrett-Jolley, 2010; Publicover, 2012)) is a labile isotopic-dependent system. These objects are known to be quite complex, although there are many approaches to their investigation. In addition to NMR labeling, it is also possible to use either Fourier transform infrared (FTIR) difference spectroscopy for isotopic study of the membrane channels and receptors (a combination of different agonists and antagonists along with the structural changes upon isotopic labeling results in the band shifts in their infrared (IR) spectra) (Baenziger, 1993) or mass-spectrometric methods, aimed for the atomic mass determination, and hence, the isotope mass analysis.

Some early investigators considered the deuterium isotope effect on permeation and gating of $\mathrm{H}^{+}$channels in the rat alveolar epithelium (DeCoursey, 1997). This effect becomes even more marked when using heavy radioisotopes, but it is very little known in such areas as «isotopic membranology» and, moreover, «isotopic channelomics». We shall assume that the reader has an idea of mass-spectrometric isotopic label determination in membrane structures, since it has long been known that mass spectrometry is an optimal tool for membrane component and constituent analysis (such as lipids (Schneiter, 1999; Gerl, 2014; Pannkuk, 2014), propeptides (Parker, 2014), membrane proteins and lipoprotein complexes (Souda, 2011; Marty, 2012; Morgner, 2012; Hopper, 2013; Laganowsky, 2013; Han, 2014)), including their labeled forms (Ruseva, 2014; Trompelt, 2014). A vast amount of technical data is provided by the stable isotope biochemical labeling (Pettelkau, 2013; Sparbier, 2013; Tang, 2013; Torde, 2013; Zhou, 2013; Dong, 2014; Herath, 2014; Huege, 2014; Liu, 2014; Popova, 2014; Wang, 2014) (including isotope-coded labeling (Gaupels, 2012; Kellermann, 2012; Biniossek, 2013; Rainczuk, 2013; Vogt, 2013; Hägglund, 2014; Pan, 2014), known since late 1990-s (Gygi, 1999) and optimally compatible with different mass spectrometry (MS) technologies (Han, 2001; Smolka, 2002; Turecek, 2002; Goshe, 2003; Tam, 2004; Hochleitner, 2005; Molloy, 2005; Schrimpf, 2005; Allison, 2006; Shiio, 2006; Kozarova, 2007; Sethuraman, 2007; Haqqani, 2008; Dong, 2011), such as GC-MS (Zhong, 2012), LC/MS (Li, 2004; Dall'asta, 2005; Prokai, 2005; Yu, 2007; Turtoi, 2010; Guo, 2012; Toyo'oka, 2012), LCMALDI (Jochim, 2011), comparative MALDI and MALDI-TOF (Tsumoto, 2007; Nelson, 2008; Koulman, 2009), 2-DE/MS (Kim, 2006), LC-MS/MS (Shen, 2007; Manini, 2010), tandem MS, including liquid chromatography-tandem mass spectrometry (Haller, 2003; Haller, 2003a; Yan, 2004; Li, 2005; Moulder, 2005; Qu, 2006; Vaughn, 2006; Butler, 2007; Zhang, 2013), quadrupole ion trap MS (Seo, 2007) etc.), nonstable isotope labeling (see, for example, (Lappin, 2010; Zhang and Katta, 2012; Grunwald, 2013) and the corresponding MS methods, known as «accelerator mass-spectrometry» (Hah, 2009; Salehpour, 2009; Lappin, 2010)) used as the metabolic and chemical structure labeling methods (Schmidt, 2014). Isotope labeling methods are indispensable tools for organic and bioorganic chemistry, which can be applied to membrane proteins, ion channels, receptors, glycolipid intercalates and other membrane structures, particularly those biochemically involved in the patch-clamp techniques.

It is also known that the methods for mass-spectrometric studies of the membrane proteins (Barrera, 2011; Was, 2014), membrane protein complexes (Barrera, 2011; Hopper, 2013) and transmembrane domains (Eichacker, 2014; Gerl, 2014) can be applied together with the selected ion recording system, based on the mass-spectrometric principles for a precise isotope ratio determination in biomedical assays when the single isotope enrichment is derived from a single label (Gruenke, 1980). The above analysis suggests a conclusion that the significance of the MSmethods for biochemical isotope ratio determinations of the membrane constituents or components can be considered as the prerequisite of the possibility of the in situ isotopic measurements based on 
or combined with the path-clamp-like principles. This conclusion is not applicable for multi-isotope mass-spectrometry, including multi-isotope mass-spectrometric imaging (McMahon, 2006; Alexandrov, 2011; Gormanns, 2012; Goto, 2012; Lechene, 2012; Steinhauser, 2012; Zhang, 2012; Steinhauser, 2013) using liquid pumping and adjustable capillary systems similar to those used in the standard patch-clamp configuration (Chen, 2008; Chen, 2010). Earlier we have already shown the possibility of the MS-patch-clamp techniques (Gradov, 2014; Gradov, 2015), but those theoretical considerations failed to provide reliable results without strong biochemical argumentation in the frame of the biophysics of the isotope-labeled agents, such as receptors, antagonists, blockers, transmitters, etc. From the above considerations one can conclude that selective amplification of the isotope uptake by the electrical diffusion potentials is a direct consequent of the ion channel-mediated flux occurring in the membrane vesicles (Garty, 1989) and the isotope flows and flux ratios in biological membranes, which are interrelated (Kedem, 1965) as in the ion exchange membranes (DeSousa, 1971; Li, 1974).

In consistence with the above approach we should list some classical objects which are used for different isotopic membranological studies as the targets and labeled / labeling compounds or visualizing agents: receptors (Pisani, 2002), receptor agonists (Rubovszky, 2003), labeled receptor inhibitors (Kapras, 2012), receptor antagonists (Thominiaux, 2006), receptor mapping agents (Gildersleeve, 1996) and neurotransmission agents visualized by PET imaging (Martin, 2013), radioligands for ion channels (Gould, 1983; Lovenberg, 1986; Marvinzon, 1988; Rauh, 1997; Fuchigami, 2012) / receptors (Jones, 1989; Pike, 1993; Rubin, 1993; Veghel, 2013), pharmacodynamic brain occupancy substances of receptor inverse agonists (Laere, 2014), channel openers (Davis-Taber, 2003), stimulants, based on neurotransmitter injection activation principles (and their precursors) (Salouros, 2013), ion channel activity reconstitution and membrane binding agents (Hamilton, 1989), etc. A problem which frequently arises from the variety of the above agents is a distinction between the mass-dependent and mass-independent isotope effects in the metabolic and other reactive redox-systems, including photolytic, thermal and electrolytic ones (Cole, 2006; Bergquist, 2007; Bhattacharya, 2009; Fujii, 2009; Sun, 2011; Jackson, 2012), which particularly can be distinguished by the mass-spectrometric methods, predominantly Inductively coupled plasma mass spectrometry (ICP-MS) both in mass-dependent (Anbar, 2001; Dauphas, 2004; Ohno, 2007; Ohno, 2013) and mass-independent (Dauphas, 2004; Cook, 2006; Malinovsky, 2011; Yang, 2011) variants, despite the fact that the cited works are mostly devoted to the isotope fractionation as the most abundant isotopic effect.

\section{Towards the mass-independent isotopic patch-clamp}

Another reasons lead to the idea of the mass-independent isotope effect-based patch-clamp studies and measurements with the main problem of the mass-independent isotope registration.

The most relevant contribution to the mass-independent isotope effect theory was made by A.L. Buchachenko (Buchachenko, 2013). The theory of the mass-independent isotope effect (also known as «magnetic isotope effect») proposed and developed by A. Buchachenko has been applied to a number of biochemical processes and objects, including the synthesis of semantids (Buchachenko, 2013a; Buchachenko, 2013b), enzymatic ATP synthesis (Buchachenko, 2008; Buchachenko, 2008a; Buchachenko, 2010; Buchachenko, 2012) and intramitochondrial phosphorylation (Buchachenko, 2004; Buchachenko, 2005; Buchachenko, 2005a), ATP synthase efficiency as a molecular machine and magnetic mechanochemistry of the phosphorylating agents (Buchachenko, 2005b; Buchachenko, 2006; Buchachenko, 2008b; Buchachenko, 2008c). It has been noted that the magnetic magnesium isotope delivered by the membranotropic cationexchanging fullerene-based nanoparticles into the myocardial cells is capable of the hypoxia-caused metabolic acidosis treatment by means of the reactivation of ATP synthesis, and thus, provides 
normalization of both intracellular proton concentration and the heart muscle cell membrane potential (Amirshahi, 2008; Rezayat, 2009; Shetab Bousheri, 2010). This is a remarkable fact, because the membrane potential is usually measured by electrophysiological methods and, moreover, patch-clamp is a classical selective technique for the single ion channel recordings on cardiomyocites (Richardson, 2010; Honda, 2011; Stoelzle, 2011; Schroder, 2012). It is even more rational to combine this method with the magnetic techniques for mass-independent / magnetic isotope effect registration. This goal can also be achieved by means of the exotic hybridization of the single calcium channel registration and the electron spin resonance spectral studies, whereof Wang Xiaoming with coauthors suggests that this complex approach may have a practical application for the registration of the calcium channel blocking effect on ventricular myocytes (Wang, 1994).

Although this method is a non-conventional one, it can provide valuable information. Another essential method applied in Buchachenko's approach was the single-spin ESR (electron spin resonance) along with the other ESR methods (Buchachenko, 2001). The former method differs significantly from the latter one, but the general principle for spin label measurements is the same in both works, and thus it can be applied for the spin labeled ion channel recording.

For example, from the beginning of the ESR-technique development, biophysicists have accepted the spin labeling technique for the simplest ion channels, such as spin-labeled derivatives of gramicidin peptides (Ivanov, 1973) and spin-labeled gramicidin itself (Dzikovski, 2011), labeled valinomycin and its analogs (Ivanov, 1974) (along with the NMR observations of the nuclear Overhauser effect of transfer of the nuclear spin polarization from one nuclear spin population to another one via cross-relaxation (Glickson, 1976; Krishna, 1978); the same method has been applied to the gramicidin (Jones, 1978; Huang, 1981; Barsukov, 1987), cecropin (Mchaourab, 1993; Mchaourab, 1994; Hung, 1999; Bhargava, 2004), zervamicin (Milov, 2002; Milov, 2010) (early labeled by deuterium (Ogrel, 1997), ${ }^{13} \mathrm{C}$ and ${ }^{15} \mathrm{~N}$ for NMR measurements (Ovchinnikova, 2003)), alamethicin (Archer, 1991; Crisma, 2007; Marsh, 2007; Bartucci, 2009; Marsh, 2009), etc. It is noteworthy that gramicidin as well as valinomycin (Gliozzi, 1996) are well known as the simple ion channels (Hu, 1993; Haldar, 2012; Wang, 2013; Basu, 2014; Chaudhuri, 2014), which can be studied by spin labeling and magnetic resonance methods (Planque, 1998; Dzikovsky, 2004), as well as ion-channel-forming valinomycin (Eastman, 1974; Meers, 1988; Kriz, 2006); zervamicin is also well known as the ion-channel-forming agent, ion channel peptide and a good model for the membrane ion channels (Agarwalla, 1992; Sansom, 1993; Ovchinnikova, 2007) with a well-studied gating mechanisms (Karle, 1991; Ballesteras, 1992; Karle, 1994) which can operate not only in the native membranes, but also in the artificial micelles and lipid bilayers (Shenkarev, 2002), and can be studied using spin labeling ESR approaches as well as other equivalent mechanisms (BarrangerMathys, 1996; Perozo, 2001; Dellisanti, 2013); colicin (also studied by spin labeling and ESR (Todd, 1989; Shin, 1993; Pulagam, 2013)) also well known as the ion channel-forming protein (Ghosh, 1994); cecropins (also studied by the spin labeling and ESR (Mchaourab, 1993; Mchaourab, 1994; Hung, 1999; Bhargava, 2004) and NMR (Holak, 1988; Sipos, 1991; Sipos, 1992; Marassi, 1999; Oh, 1999; Yagi-Utsumi, 2013)) known as the ion channel-forming peptide (Juvvadi, 1996; Bechinger, 1997) and a simple ion channel model compound incorporated into planar lipid membranes for membrane biomimetics (Christensen, 1988), based on the objective model approaches (Durell, 1992).

It is noteworthy that many membrane channels, receptors and other membrane structures are $\mathrm{Mg}^{2+}$-dependent, while its isotopes were used in the studies performed by A.L. Buchachenko and his coauthors (Amirshahi, 2008; Rezayat, 2009; Shetab Bousheri, 2010). Thus, it is well accepted that CorA is the major transport system responsible for $\mathrm{Mg}^{2+}$ uptake in bacteria and can functionally substitute its homolog Mrs2p in the yeast inner mitochondrial membrane (Dalmas, 2014). There are also conformational changes in a GAAA tetraloop receptor upon $\mathrm{Mg}^{2+}$-dependent conditions (Qin, 2005). Despite the receptors and transducers which are $\mathrm{Mg}$-dependent structures at the molecular 
level, one can also give an example of the Mg-dependent phase, microhydrodynamical and rheological properties of the membranes at both micro- and mesoscopic levels (Ogiso, 1981; Yang, 1983; East, 1984; Sorensen, 1987). Due to the effects coupled with ATP, AMP, adenylate cyclase activators (Du, 1982; Yang, 1988; Zhang, 1989; Coan, 1993; Negash, 2000; Zimmermann, 2000) $\mathrm{Mg}^{2+}$ participates in the membrane bioenergetics. Since different metal ions $\left(\mathrm{Fe}^{2+}, \mathrm{Cu}^{2+}, \mathrm{Ca}^{2+}, \mathrm{Mg}^{2+}\right)$ influence the transmembrane transport differently (Lohmann, 1986), to date it is possible to postulate the existence of a direct relationships between the membrane metallomics (Klein, 2011) of $\mathrm{Mg}^{2+}$ with the membrane bioenergetics. It should be noted that the above idea is also applicable to the photosynthetic bioenergetical structures, since there has been reported an effect of the magnesium ions on the structural state of the thylakoid membranes and the kinetics of the electron transport between the two photosystems in bean chloroplasts (Tikhonov, 1980), and it was also found that $\mathrm{Mg}^{2+}$-induced lipid phase transition in the thylakoid membranes can be reversed by the anions (Jajoo, 1994). Similar Mg-dependent mechanisms determine the bioenergetics in the sarcoplasmic reticulum membranes by magnesium-dependent adenosine triphosphatase (Kirino, 1978).

Hence, it is not surprising that $\mathrm{Mg}^{2+}$ is widely involved in the biochemical pathways as a cross-agent and / or a physiological indicator in spin labeling methods (in particular - with nitroxyl (Du, 1982) and biosynthetically generated phospholipid spin labels (Takeuchi, 1981)). For the neurons being classical objects for the patch-clamp experiments, spin labels are frequently used (including the studies of the anesthetic effects upon the membrane (Wang, 1982)). At the same time it is obvious that divalent cations, including $\mathrm{Mg}^{2+}$, significantly affect the results of the spin label studies of the brain membranes (Viret, 1976), as well as other biomembranes in the context of their biosynthetic and bioenergetical activity, e.g. in Esherichia coli (Takeuchi, 1978). A classical ion channel - valinomycin, under NMR studies of its membrane-associated location and ionbinding demonstrates an interesting effect in presence of the bivalent ions: $\mathrm{Rb}^{+}$and $\mathrm{K}^{+}$show $1: 1$ binding to valinomycin, whereas the stoichiometry of $\mathrm{Cs}^{+}$and $\mathrm{Ba}^{2+}$ is not certain (Meers, 1988). This fact is of great importance, since the investigation of the surface potential in phospholipid vesicles by a spin label relaxation method reveals the coupling between the surface potential asymmetry and the parameters measured using spin labeling (Sundberg, 1986), as well as the dependence of the transmembrane electrical currents on the differently charged spin-labeled hydrophobic ions (Cafiso, 1982). The above considerations suggest that it is reasonable and necessary to develop mass-independent isotopic patch-clamp, including its variation combined with the magnetic ESR measurements and spin labeling techniques. This can be illustrated by an example of the postsynatpic membrane acetylcholinesterase and acetylcholine receptors of the electric organ of Torpedo marmorata. Transmembrane potential of the postsynatpic membrane can be considered as the source of the surface bioelectrogenesis of Torpedo marmorata electric organ, i.e. to be a subject of the high-voltage electrophysiology and EHV patch-clamp / voltage clamp. At the same time it is possible to perform ESR study of the postsynatpic membrane acetylcholinesterase of Torpedo marmorata electric organ (Sentjurc, 1976) and of the association of the spin-labeled local agents at the hydrophobic surface of acetylcholine receptor in the native membranes from Torpedo marmorata (Horvath, 1990) or of the effect of general anesthetics on the lipid-protein interactions in acetylcholine receptor enriched membranes from Torpedo nobiliana using nitroxide spin-labels (Frazer, 1990). Considering that since 1970-1980-th patch-clamp studies (Fenwick, 1982; Akaike, 1984; Allen, 1984; Gallacher, 1986; Methfessel, 1986; Brett, 1988; Kuba, 1989; Pennington, 1990; Nooney, 1992; Milone, 1994; Buisson, 1996; Keleshian, 2000; Re, 2003; Matsubayashi, 2004; Robertson, 2013; Hao, 2015) and voltage clamp studies (Sano, 1970; Anderson, 1973; Bolton, 1975; Sachs, 1977; Fischbach, 1978; Bregestovski, 1979; Chad, 1979; McCandless, 1981; Wachtel, 1981; Takeyasu, 1983; Hirano, 1987; Woody, 1987; Cachelin, 1989; 
Nelson, 1992; Simon, 1992; Voigt, 2010) on acetylcholine or its functionally complementary agents, therefore a similar patch-clamp / voltage-clamp approach is particularly applicable to the electrogenerating membrane structures, including neuromimetic ones. From the standpoint of molecular biomimetics and QSAR / QSPR (quantitative structure-activity relationship / quantitative structure-property relationships) it is interesting to mention that ESR studies using different spin labeled acetylcholine analogs are frequently used in the studies of the cholinergic receptor (Rosen, 1975).

Another advantage of the Buchachenko's approach is the possibility to work with the singlet molecular oxygen (Martinez, 2005; Buchachenko, 2006a; Buchachenko, 2011), including the studies on the photo-oxidation of water by molecular oxygen considering the isotope exchange and isotope effects (Buchachenko, 2011). The method described in the above cited paper can also be applied to the studies of the light-induced hindrance of spin label motion in the lumen of spinach thylakoids (Nesbitt, 1980) using patch-clamp techniques, since modern patch clamp techniques for studying the ion channels in organelles (Keller, 1992) allow not only to perform a patchclamp study of the vascular plant chloroplasts (Muniz, 1995), but also a patch-clamp study of the voltage-dependent anion channel in the thylakoid membrane (Pottosin, 1995). This makes possible in future to apply ESR magnetic isotope patch-clamp method for studying the activity of the oxygen channels (Ivanov, 2007; Frankel, 2012) and oxygen sensitive channels (Lopez-Barneo, 2004; Otsubo, 2006). The implementation of the above technique with the ESR setups equipped with a capillary connected to the standard patch-clamp registration system is not difficult, since the detection of the singlet oxygen (Schaich, 1976; Cannistraro, 1977; Moan, 1979; Feix, 1991; Song, 1999; Lavi, 2004; Jung, 2009), as well as the other reactive oxygen species (Capani, 2001; Kasazaki, 2003; Yamato, 2003; Cao, 2005; Xu, 2007; Sawada, 2010; Saita, 2012; Lee, 2013; Qi, 2016) within their physiological and biochemical functions in the cellular structures, is long performed using ESR methods.

It is also possible to combine the conventional isotope and ESR studies by using the isotope label method (isotope-substituted, membrane-impermeant bifunctional spin label for the studies of the dynamics of the membrane proteins; for example, in application to the anion-exchange channel (Anjaneyulu, 1988)). It should be also mentioned here that the oxygen isotopes have been already used for a long time as the labels in molecular biology and biophysical chemistry, being the classical research tools with ${ }^{18} \mathrm{O}$ (Burstein, 1974; Puzo, 1977; Sleep, 1978; Marnett, 1979; Hackney, 1980; Pickett, 1981; Rosenberg, 1981; Rosenberg, 1981a; Stempel, 1986; Ponnusamy, 1986; Aissa, 1988; McLeish, 1989; Risley, 1989; Murphy, 1990; Tian, 1994; Horvitz, 2001; Martinez, 2002; Ye, 2003; Staes, 2004; Crean, 2005; Niles, 2009; Schliep, 2010; Fernandez-de-Cossio, 2011; Melby, 2011; Qian, 2011; Kanady, 2013; Sha, 2014; Stingl, 2014) being more popular than ${ }^{15} \mathrm{O}$ (West, 1968; Subramanyam, 1977; Berridge, 1986; Berridge, 1990; Moerlein, 1993) and other ones.

This suggests the possibility to apply them for the studies of the oxygen- and redoxdependent ion channels, as well as for the analysis of their redox regulation (Elliott, 1997; Carpaneto, 1999; Anzai, 2000; Choudhary, 2002; Hall, 2003; Matalon, 2003; Wang, 2003; Buck, 2004; Schön, 2005; Antonenko, 2006; Tsikolia, 2009; Petrotchenko, 2011; Fogle, 2015), including the classical Marinov ion channel redox model (Marinov, 1991), and hence, a redox-dependent voltage clamp (Hoffman, 1976; Hescheler, 1989; Puppi, 1991; Haddad, 1993; Shattock, 1993).

\section{References}

1. Abarca-Heideman K, Duchardt-Ferner E, Woehnert J, Rothberg BS. Isotope labeling strategies for analysis of an ion channel cytoplasmic domain by NMR spectroscopy. Meth Mol Biol 2013, 998:289-300.

2. Agarwalla S, Mellor IR, Sansom MS, Karle IL, Flippen-Anderson JL, Uma K, Krishna K, Sukumar M, Balaram P. Zervamicins, a structurally characterised peptide model for 
membrane ion channels. Biochem Biophys Res Comm 1992, 186(1):8-15.

3. Aissa M, Hatch GE. Method for tracing oxygen-18 in vivo: application to ozone dosimetry in animals. Bas Life Sci 1988, 49:195-197.

4. Akaike A, Ikeda SR, Brookes N, Pascuzzo GJ, Rickett DL, Albuquerque EX. The nature of the interactions of pyridostigmine with the nicotinic acetylcholine receptor-ionic channel complex. II. Patch clamp studies. Mol Pharmacol 1984, 25(1):102-112.

5. Alexandrov T, Meding S, Trede D, Kobarg JH, Balluff B, Walch A, Thiele H, Maass P. Super-resolution segmentation of imaging mass spectrometry data: Solving the issue of low lateral resolution. J Proteomics 2011, 75(1):237-245.

6. Allen $\mathrm{CN}$, Akaike A, Albuquerque EX. The frog interosseal muscle fiber as a new model for patch clamp studies of chemosensitive- and voltage-sensitive ion channels: actions of acetylcholine and batrachotoxin. J Physiol 1984, 79(4):338-343.

7. Allison WT, Veldhoen KM, Hawryshyn CW. Proteomic analysis of opsins and thyroid hormone-induced retinal development using isotope-coded affinity tags (ICAT) and mass spectrometry. Mol Vis 2006, 12:655-672.

8. Amirshahi N, Alyautdin RN, Sarkar S, Rezayat SM, Orlova MA, Trushkov IV, Buchachenko AL, Kuznetsov DA. Fullerene-based low toxic nanocationite particles (porphyrin adducts of cyclohexyl fullerene- $\mathrm{C}_{60}$ to treat hypoxia-induced mitochondrial dysfunction in mammalian heart muscle. Arch Med Res 2008, 39(6):549-559.

9. Anbar AD, Knab KA, Barling J. Precise determination of massdependent variations in the isotopic composition of molybdenum using MC-ICPMS. Anal Chem 2001, 73(7):1425-1431.

10. Anderson CR, Stevens CF. Voltage clamp analysis of acetylcholine produced endplate current fluctuations at frog neuromuscular junction. J Physiol 1973, 235(3):655-691.

11. Anjaneyulu PS, Beth AH, Sweetman BJ, Faulkner LA, Staros JV. Bis(sulfo-Nsuccinimidyl) $\left[{ }^{15} \mathrm{~N},{ }^{2} \mathrm{H}_{16}\right]$ doxyl-2-spiro-4'-pimelate, a stable isotope-substituted, membraneimpermeant bifunctional spin label for studies of the dynamics of membrane proteins: application to the anion-exchange channel in intact human erythrocytes. Biochemistry 1988, 27(18):6844-6851.

12. Antonenko YN, Stoilova TB, Kovalchuk SI, Egorova NS, Pashkovskaya AA, Sobko AA, Kotova EA, Surovoy AY. Redox-regulated ion channel activity of a cysteinecontaining gramicidin A analogue. Biochim Biophys Acta 2006, 1758(4):493-498.

13. Anzai K, Ogawa K, Ozawa T, Yamamoto H. Oxidative modification of ion channel activity of ryanodine receptor. Antioxid Redox Signal 2000, 2(1):35-40.

14. Archer SJ, Ellena JF, Cafiso DS. Dynamics and aggregation of the peptide ion channel alamethicin. Measurements using spin-labeled peptides. Biophys $J$ 1991, 60(2):389-398.

15. Baenziger JE, Miller KW, Rothschild KJ. Fourier transform infrared difference spectroscopy of the nicotinic acetylcholine receptor: evidence for specific protein structural changes upon desensitization. Biochemistry 1993, 32(20):5448-5454.

16. Ballesteros JA, Weinstein $\mathrm{H}$. The role of Pro/Hyp-kinks in determining the transmembrane helix length and gating mechanism of a [Leu]zervamicin channel. Biophys $J$, 1992, 62(1):110-111.

17. Barranger-Mathys M, Cafiso DS. Membrane structure of voltage-gated channel forming peptides by site-directed spin-labeling. Biochemistry 1996, 35(2):498-505.

18. Barrera NP, Robinson CV. Advances in the mass spectrometry of membrane proteins: from individual proteins to intact complexes. Ann Rev Biochem 2011, 80:247-271.

19. Barrett-Jolley R, Lewis R, Fallman R, Mobasheri A. The emerging chondrocyte channelome. Front Physiol 2010, 1(135):1-11. 
20. Barsukov IL, Arsen'ev AS, Bystrov VF. Spatial structure of gramicidin A in organic solvents. ${ }^{1} \mathrm{H}-\mathrm{NMR}$ analysis of conformation heterogeneity in ethanol. Bioorg Chem 1987, 13(11):1501-1522.

21. Bartucci R, Guzzi R, Sportelli L, Marsh D. Intramembrane water associated with TOAC spin-labeled alamethicin: electron spin-echo envelope modulation by $\mathrm{D}_{2} \mathrm{O}$. Biophys $J$ 2009, 96(3):997-1007.

22. Basu I, Chattopadhyay A, Mukhopadhyay C. Ion channel stability of Gramicidin A in lipid bilayers: effect of hydrophobic mismatch. Biochim Biophys Acta 2014, 1838(1):328-338.

23. Bechinger B. Structure and functions of channel-forming peptides: magainins, cecropins, melittin and alamethicin. J Membr Biol 1997, 156(3):197-211.

24. Bergquist BA, Blum JD. Mass-dependent and independent fractionation of $\mathrm{Hg}$ isotopes by photoreduction in aquatic systems. Science 2007, 318(5849):417-420.

25. Berridge MS, Franceschini MP, Tewson TJ, Gould KL. Preparation of oxygen-15 butanol for positron tomography. J Nucl Med 1986, 27(6):834-837.

26. Berridge MS, Cassidy EH, Terris AH. A routine, automated synthesis of oxygen15-labeled butanol for positron tomography. J Nucl Med 1990, 31(10):1727-1731.

27. Bhargava K, Feix JB. Membrane binding, structure, and localization of cecropinmellitin hybrid peptides: a site-directed spin-labeling study. Biophys J 2004, 86(1 Pt 1):329-336.

28. Bhate MP, Wylie BJ, Thompson A, Tian L, Nimigean C, McDermott AE. Preparation of uniformly isotope labeled KcsA for solid state NMR: expression, purification, reconstitution into liposomes and functional assay. Protein Expr Purif 2013, 91(2):119-124.

29. Bhattacharya SK, Savarino J, Luz B. Mass-dependent isotopic fractionation in ozone produced by electrolysis. Anal Chem 2009, 81(13):5226-5232.

30. Biniossek ML, Lechel A, Rudolph KL, Martens UM, Zimmermann S. Quantitative proteomic profiling of tumor cell response to telomere dysfunction using isotopecoded protein labeling (ICPL) reveals interaction network of candidate senescence markers. $J$ Proteomics 2013, 91:515-535.

31. Bolton TB. Effects of stimulating the acetylcholine receptor on the currentvoltage relationships of the smooth muscle membrane studied by voltage clamp of potential recorded by micro-electrode. J Physiol 1975, 250(1):175-202.

32. Bregestovksi PD, Bukharaeva EA, Iljin VI. Voltage clamp analysis of acetylcholine receptor desensitization in isolated mollusc neurones. J Physiol 1979, 297:581595.

33. Brett RS, Dilger JP, Yland KF. Isoflurane causes «flickering» of the acetylcholine receptor channel: observations using the patch clamp. Anesthesiology 1988, 69(2):161-170.

34. Buchachenko AL, Dalidchik FI, Shub BR. Single spin ESR. Chem Phys Lett 2001, 340(1-2):103-108.

35. Buchachenko AL, Kuznetsov DA, Arkhangel'sky SE, Orlova MA, Markaryan AA, Berdieva AG, Khasigov PZ. Dependence of mitochondrial ATP synthesis on the nuclear magnetic moment of magnesium ions. Dokl Biochem Biophys 2004, 369:197-199.

36. Buchachenko AL, Kouznetsov DA, Arkhangelsky SE, Orlova MA, Markarian AA. Spin biochemistry: intramitochondrial nucleotide phosphorylation is a magnesium nuclear spin controlled process. Mitochondrion 2005, 5(1):67-69.

37. Buchachenko AL, Kouznetsov DA, Arkhangelsky SE, Orlova MA, Markarian AA. Spin biochemistry: magnetic ${ }^{24} \mathrm{Mg}_{-}{ }^{25} \mathrm{Mg}-{ }^{26} \mathrm{Mg}$ isotope effect in mitochondrial ADP phosphorylation. Cell Biochem Biophys 2005a, 43(2):243-251.

38. Buchachenko A.L., Kouznetsov D.A., Orlova M.A., Markarian A.A. Magnetic isotope effect of magnesium in phosphoglycerate kinase phosphorylation. Proc Natl Acad Sci USA 2005b, 102(31):10793-10796. 
39. Buchachenko AL, Kuznetsov DA. Magnesium magnetic isotope effect: A key to the mechanochemistry of phosphorylating enzymes as molecular machines. Mol Biol (Mosk) 2006, 40(1):9-15.

40. Buchachenko AL, Ivanov VL, Roznyatovsky VA, Ustynyuk YA. Magnetic isotope effect in the photolysis of organotin compounds. J Phys Chem A 2006a, 110 (11):3857-3859.

41. Buchachenko AL, Kuznetsov DA. Magnetic field affects enzymatic ATP synthesis. J Am Chem Soc 2008, 130(192):12868-12869.

42. Buchachenko AL, Kouznetsov DA, Breslavskaya NN, Orlova MA. Magnesium isotope effects in enzymatic phosphorylation. J Phys Chem B 2008a, 112(8):2548-2556.

43. Buchachenko AL, Kouznetsov DA. Efficiency of ATP synthase as a molecular machine. Biophysics 2008b, 153(3):219-222.

44. Buchachenko AL, Kouznetsov DA. How mechanical energy of phosphorylating enzymes transforms into the energy of chemical bonds? Mend Comm 2008c, 18(2):63-66.

45. Buchachenko AL, Kuznetsov DA, Breslavskaya NN. Ion-radical mechanism of enzymatic ATP synthesis: DFT calculations and experimental control. J Phys Chem B 2010, 114(6):2287-2292.

46. Buchachenko AL, Dubinina EO. Photo-oxidation of water by molecular oxygen: isotope exchange and isotope effects. J Phys Chem A 2011, 115(15):3196-3200.

47. Buchachenko AL, Kuznetsov DA, Breslavskaya NN. Chemistry of enzymatic ATP synthesis: an insight through the isotope window. Chem Rev 2012, 112(4):2042-2058.

48. Buchachenko AL. Mass-independent isotope effects. J Phys Chem B 2013, 117(8):2231-2238.

49. Buchachenko AL, Orlov AP, Kuznetsov DA, Breslavskaya NN. Magnetic isotope and magnetic field effects on the DNA synthesis. Nucleic Acids Res 2013a, 41(17):8300-8307.

50. Buchachenko AL, Orlov AP, Kuznetsov DA, Breslavskaya NN. Magnetic control of the DNA synthesis. Chem Phys Lett 2013b, 586:138-142.

51. Buck LT. Adenosine as a signal for ion channel arrest in anoxia-tolerant organisms. Comp Biochem Physiol B Biochem Mol Biol 2004, 139(3):401-114.

52. Buisson B, Gopalakrishnan M, Arneric SP, Sullivan JP, Bertrand D. Human alpha4beta2 neuronal nicotinic acetylcholine receptor in HEK 293 cells: A patch-clamp study. $J$ Neurosci 1996, 16(24):7880-7891.

53. Burstein S, Middleditch BS. Enzymatic formation of (20R,22R)-20,22dihydroxycholesterol from cholesterol and a mixture of ${ }^{16} \mathrm{O}_{2}$ and ${ }^{18} \mathrm{O}_{2}$ : random incorporation of oxygen atoms. Biochem Biophys Res Commun 1974, 61(2):692-697.

54. Butler GS, Overall CM. Proteomic validation of protease drug targets: pharmacoproteomics of matrix metallo-proteinase inhibitor drugs using isotope-coded affinity tag labelling and tandem mass spectrometry. Curr Pharm Des 2007, 13(3):263-270.

55. Cachelin AB, Colquhoun D. Desensitization of the acetylcholine receptor of frog end-plates measured in a Vaseline-gapvoltage clamp. J Physiol 1989, 415:159-188.

56. Cafiso DS, Hubbell WL. Transmembrane electrical currents of spin-labeled hydrophobic ions. Biophys $J$ 1982, 39(3):263-272.

57. Cannistraro S, Van de Vorst A. ESR and optical absorption evidence for free radical involvement in the photosensitizing action of furocoumarin derivatives and for their singlet oxygen production. Biochim Biophys Acta 1977, 476(2):166-177.

58. Cao Y, Guo P, Xu Y, Zhao B. Simultaneous detection of NO \& ROS by ESR in biological systems. Met. Enzymol 2005, 396:77-83.

59. Capani F, Loidl CF, Aguirre F, Piehl L, Facorro G, Hager A, De Paoli T, Farach H, Pecci-Saavedra J. Changes in reactive oxygen species (ROS) production in rat brain during 
global perinatal asphyxia: an ESR study. Brain Res 2001, 914(1-2):204-207.

60. Carpaneto A, Cantù AM, Gambale F. Redox agents regulate ion channel activity in vacuoles from higher plant cells. FEBS Lett 1999, 442(2-3):129-132.

61. Chad JE, Kerkut GA, Walker RJ. Ramped voltage clamp study of the action of acetylcholine on three types of neurons in the snail (Helix aspersa) brain. Comp Biochem Physiol C 1979, 63C(2):269-278.

62. Chaudhuri A, Haldar S, Sun H, Koeppe RE, Chattopadhyay A. Importance of indole N-H hydrogen bonding in the organization and dynamics of gramicidinchannels. Biochim Biophys Acta 2014, 1838 (1):419-428.

63. Chen Y, Allegood J, Liu Y, Wang E, Cachón-Gonzalez B, Cox TM, Merrill AH, Sullards MC. Imaging MALDI mass spectrometry using oscillating capillary nebulizer matrix coating system and its application to analysis of lipids in brain from a mouse model of TaySachs / Sandhoff disease. Anal Chem 2008, 80(8):2780-2788.

64. Chen Y, Liu Y, Allegood J, Wang E, Cachón-González B, Cox TM, Merrill AH, Sullards MC. Imaging MALDI mass spectrometry of sphingolipids using an oscillating capillary nebulizer matrix application system. Methods Mol Biol 2010, 656:131-146.

65. Choudhary G, Dudley SC. Heart failure, oxidative stress, and ion channel modulation. Congest Heart Fail 2002, 8(3):148-155.

66. Christensen B, Fink J, Merrifield RB, Mauzerall D. Channel-forming properties of cecropins and related model compounds incorporated into planar lipid membranes. Proc Natl Acad Sci USA 1988, 85(14):5072-5076.

67. Coan C, Jakobs P, Ji JY, Murphy AJ. Sarcoplasmic reticulum calcium ATPase. Labeling of a putative $\mathrm{Mg}^{2+}$ site by reaction with a carbodiimide and a spin-label. FEBS Lett 1993, 335(1):33-36.

68. Cole AS, Boering KA. Mass-dependent and non-mass-dependent isotope effects in ozone photolysis: resolving theory and experiments. J Chem Phys 2006, 125(18): 184301.

69. Cook DL, Wadhwa M, Janney PE, Dauphas N, Clayton RN, Davis AM. High precision measurements of non-mass-dependent effects in nickel isotopes in meteoritic metal via multicollector ICPMS. Anal Chem 2006, 78(24):8477-8484.

70. Crean C, Geacintov NE, Shafirovich V. Oxidation of guanine and 8-oxo-7,8dihydroguanine by carbonate radical anions: insight from oxygen-18 labeling experiments. Angew Chem Int Ed Engl 2005, 44(32):5057-5060.

71. Crisma M, Peggion C, Baldini C, Maclean EJ, Vedovato N, Rispoli G, Toniolo C. Crystal structure of a spin-labeled, channel-forming alamethicin analogue. Angew Chem Int Ed Engl 2007, 46(12):2047-2050.

72. Dall'asta C, Sforza S, Moseriti A, Galaverna G, Dossena A, Marchelli R. An innovative LC/MS approach applied to the determination of zeralenone in maize: Alternate Isotope-coded Derivatization Assay (AIDA). Mycotoxin Res 2005, 21(4):218-223.

73. Dalmas O, Sompornpisut P, Bezanilla F, Perozo E. Molecular mechanism of $\mathrm{Mg}^{2+}$-dependent gating inCorA. Nature Comm 2014, 5(3590):1-11.

74. Dauphas N, Janney PE, Mendybaev RA, Wadhwa M, Richter FM, Davis AM, van Zuilen M, Hines R, Foley CN. Chromatographic separation and multicollection-ICPMS analysis of iron. Investigating mass-dependent and -independent isotope effects. Anal Chem 2004, 76(19):5855-5863.

75. Davis-Taber R, Molinari EJ, Altenbach RJ, Whiteaker KL, Shieh CC, Rotert G, Buckner SA, Malysz J, Milicic I, McDermott JS, Gintant GA, Coghlan MJ, Carroll WA, Scott VE, Gopalakrishnan M. [ $\left.{ }^{125} \mathrm{I}\right] \mathrm{A}-312110$, a novel high-affinity 1,4-dihydropyridine ATP-sensitive K+ channel opener: characterization and pharmacology of binding. Mol Pharmacol 2003, 64(1):143-153.

76. DeCoursey TE, Cherny VV. Deuterium isotope effects on permeation and gating 
of proton channels in rat alveolar epithelium. J Gen Physiol 1997, 109(4):415-434.

77. Dellisanti CD, Ghosh B, Hanson SM, Raspanti JM, Grant VA, Diarra GM, Schuh AM, Satyshur K, Klug CS, Czajkowski C. Site-directed spin labeling reveals pentameric ligandgated ion channel gating motions. PLoS Biol 2013, 11(11):e1001714.

78. DeSousa RC, Li JH, Essig A. Flux ratios and isotope interaction in an ion exchange membrane. Nature 1971, 231(5297):44-45.

79. Dong L, Li J, Li L, Li T, Zhong H. Comparative analysis of S-fatty acylation of gel-separated proteins by stable isotope-coded fatty acid transmethylation and mass spectrometry. Nat Protoc 2011, 6(9):1377-1390.

80. Dong Y, Tang M, Song H, Li R, Wang C, Ye H, Qiu N, Zhang Y, Chen L, Wei Y. Characterization of metabolic profile of honokiol in rat feces using liquid chromatography coupled with quadrupole time-of-flight tandem mass spectrometry and ${ }^{13} \mathrm{C}$ stable isotope labeling. J Chromatogr B: Analyt Technol Biomed Life Sci 2014, 953-954:20-29.

81. Du ZH, Mansour TE. Effect of adenylate cyclase activators and $\mathrm{Mg}^{2+}$ on the binding and the electron spin resonance spectra of $\mathrm{N}$-methylmaleimide nitroxide in membrane particles from the liver fluke Fasciola hepatica. Biochim Biophys Acta 1982, 687(2):257-264.

82. Durell SR, Raghunathan G, Guy HR. Modeling the ion channel structure of cecropin. Biophys J 1992, 63(6):1623-1631.

83. Dzikovski BG, Borbat PP, Freed JH. Spin-labeled gramicidin a: channel formation and dissociation. Biophys $J$ 2004, 87(5):3504-3517.

84. Dzikovski BG, Borbat PP, Freed JH. Channel and nonchannel forms of spinlabeled gramicidin in membranes and their equilibria. J Phys Chem B 2011, 115(1):176-185.

85. East JM, Jones OT, Simmonds AC, Lee AG. Membrane fluidity is not an important physiological regulator of the $\mathrm{Ca}^{2+}-\mathrm{Mg}^{2+}$-dependent ATPase of sarcoplasmic reticulum. J Biol Chem 1984, 259(13):8070-8071.

86. Eastman MP. Electron spin resonance studies of valinomycin Na+-TCNE-ion pairs. J Chem. Soc Chem Commun 1974, 19:789-790.

87. Eichacker LA, Granvogl B, Mirus O, Müller BC, Miess C, Schleiff E. Hiding behind hydrophobicity. Trans-membrane segments in mass spectrometry. J Biol Chem 2004, 279(49):50915-50922.

88. Elliott SJ, Koliwad SK. Redox control of ion channel activity in vascular endothelial cells by glutathione. Microcirculation 1997, 4(3):341-347.

89. Feix JB, Kalyanaraman B. Production of singlet oxygen-derived hydroxyl radical adducts during merocyanine-540-mediated photosensitization: analysis by ESR-spin trapping and HPLC with electrochemical detection. Arch Biochem Biophys 1991, 291(1):43-51.

90. Fenwick EM, Marty A, Neher E. A patch-clamp study of bovine chromaffin cells and of their sensitivity to acetylcholine. J Physiol 1982, 331:577-597.

91. Fernandez-de-Cossio J. Mass spectrum patterns of ${ }^{18} \mathrm{O}$-tagged peptides labeled by enzyme-catalyzed oxygen exchange. Anal Chem 2011, 83(8):2890-2896.

92. Fischbach GD, Lass Y. Acetylcholine noise in cultured chick myoballs: a voltage clamp analysis. J Physiol 1978, 280:515-526.

93. Fogle KJ, Baik LS, Houl JH, Tran TT, Roberts L, Dahm NA, Cao Y, Zhou M, Holmes TC. CRYPTO-CHROME-mediated phototransduction by modulation of the potassium ion channel $\beta$-subunit redox sensor. Proc Natl Acad Sci USA 2015, 112(7):2245-2250.

94. Frankel LK, Sallans L, Limbach PA, Bricker TM. Identification of oxidized amino acid residues in the vicinity of the $\mathrm{Mn}_{4} \mathrm{CaO}_{5}$ cluster of Photosystem II: implications for the identification of oxygen channels within the Photosystem. Biochemistry 2012, 51(32):63716377. 
95. Fraser DM, Louro SR, Horváath LI, Miller KW, Watts A. A study of the effect of general anesthetics on lipid-protein interactions in acetylcholine receptor enriched membranes from Torpedo nobiliana using nitroxide spin-labels. Biochemistry 1990, 29(11):2664-2669.

96. Fuchigami T, Haradahira T, Fujimoto N, Okauchi T, Maeda J, Suzuki K, Suhara T, Yamamoto F, Sasaki S, Mukai T, Yamaguchi H, Ogawa M, Magata Y, Maeda M. Difference in brain distributions of carbon 11-labeled 4-hydroxy-2 $\left({ }^{1} \mathrm{H}\right)$-quinolones as PET radioligands for the glycine-binding site of the NMDA ion channel. Nucl Med Biol 2008, 35(2):203-212.

97. Fujii T, Moynier F, Uehara A, Abe M, Yin QZ, Nagai T, Yamana H. Massdependent and mass-independent isotope effects of zinc in a redox reaction. $J$ Phys Chem A 2009, 113(44):12225-12232.

98. Gallacher DV, Morris AP. A patch-clamp study of potassium currents in resting and acetylcholine-stimulated mouse submandibular acinar cells. J Physiol.1986, 373: 379-395.

99. Garty H, Karlish SJ. Ion channel-mediated fluxes in membrane vesicles: selective amplification of isotope uptake by electrical diffusion potentials. Methods Enzymol 1989, 172:155-164.

100. Gaupels F, Sarioglu H, Beckmann M, Hause B, Spannagl M, Draper J, Lindermayr C, Durner J. Deciphering systemic wound responses of the pumpkin extrafascicular phloem by metabolomics and stable isotope-coded protein labeling. Plant Physiol 2012, 160(4):2285-2299.

101. Gerl MJ, Sachsenheimer T, Grzybek M, Coskun U, Wieland FT, Brügger B. Analysis of Transmembrane Domains and Lipid Modified Peptides with Matrix-Assisted Laser Desorption Ionization-Time-of-Flight Mass Spectrometry. Anal Chem 2014, 86(8):3722-3726.

102. Ghosh P, Mel SF, Stroud RM. The domain structure of the ion channel-forming protein colicin Ia. Nat Struct Biol 1994, 1(9):6597-6604.

103. Gildersleeve DL, Van Dort ME, Johnson JW, Sherman PS, Wieland DM. Synthesis and evaluation of $\left[{ }^{123} \mathrm{I}\right]$-iodo-PK11195 for mapping peripheral-type benzodiazepine receptors $\left(\omega_{3}\right)$ in heart. Nucl Med Biol 1996, 23(1):23-28.

104. Glickson JD, Gordon SL, Pitner P, Agresti DG, Walter R. Intramolecular ${ }^{1} \mathrm{H}$ nuclear Overhauser effect study of the solution conformation of valinomycin in dimethyl sulfoxide. Biochemistry 1976, 15(26):5721-5729.

105. Gliozzi A, Robello M, Fittabile L, Relini A, Gambacorta A. Valinomycin acts as a channel in ultrathin lipid membranes. Biochim Biophys Acta 1996, 1238(1):1-3.

106. Gormanns P, Reckow S, Poczatek JC, Turck CW, Lechene C. Segmentation of multi-isotope imaging mass spectrometry data for semi-automatic detection of regions of interest. PLoS One 2012, 7(2):e30576.

107. Goshe MB, Smith RD. Stable isotope-coded proteomic mass spectrometry. Curr Opin Biotechnol 2003, 14(1):101-109.

108. Goto K, Waki M, Takahashi T, Kadowaki M, Setou M. High-resolution multiisotope imaging mass spectrometry enables visualization of stem cell division and metabolism. Chembiochem 2012, 13(8):1103-1106.

109. Gould RJ, Murphy KM, Snyder SH. Studies on voltage-operated calcium channels using radioligands. CSH Symp Quant Biol 1983, 48(1):355-362.

110. Gradov OV, Gradova MA. On the possibility of «MS-patch-clamp» or mass spectrometry hybridization with patch-clamp setups for single cell metabolomics and channelomics. In Int. Workshop «Structure and Functions of Biomembranes» (BIOMEMBRANES'14): 29 ${ }^{\text {th }}$ Sept. $-3^{\text {rd }}$ Oct. 2014; MIPT (Moscow Institute of Physics and Technology), Dolgoprudny; 2014:105.

111. Gradov O, Gradova M. «MS-Patch-Clamp» or the Possibility of Mass Spectrometry Hybridization with Patch-Clamp Setups for Single Cell Metabolomics and Channelomics. Advances in Biochemistry 2015, 3:66-71. 
112. Gruenke LD, Craig JC, Bier DM. An improved selected ion recording system for precise isotope ratio determination. Biomed Mass Spectrom 1980, 7(9):381-384.

113. Grunwald H, Hargreaves P, Gebhardt K, Klauer D, Serafyn A, Schmitt-Hoffmann A, Schleimer M, Schlotterbeck G, Wind M. Experiments for a systematic comparison between stable-isotope-(deuterium) labeling and radio- ${ }^{14} \mathrm{C}$ ) labeling for the elucidation of the in vitro metabolic pattern of pharmaceutical drugs. J Pharm Biomed Anal 2013, 85:138-144.

114. Guo J, Prokai-Tatrai K, Prokai L. Relative quantitation of protein nitration by liquid chromatography-mass spectrometry using isotope-coded dimethyl labeling and chemoprecipitation. J Chromatogr A 2012, 1232:266-275.

115. Gygi SP, Rist B, Gerber SA, Turecek F, Gelb MH, Aebersold R. Quantitative analysis of complex protein mixtures using isotope-coded affinity tags. Nat Biotechnol 1999, 17(10): 994-999.

116. Hackney DD, Stempel KE, Boyer PD. Oxygen-18 probes of enzymic reactions of phosphate compounds. Methods Enzymol 1980, 64:60-83.

117. Haddad GG, Jiang C. Mechanisms of anoxia-induced depolarization in brainstem neurons: in vitro current and voltage clamp studies in the adult rat. Brain Res 1993, 625(2):261268.

118. Hah SS. Determination of protein-ligand interactions using accelerator mass spectrometry: modified crosslinking assay. Anal Sci 2009, 25(5):731-733.

119. Haldar S, Chaudhuri A, Gu H, Koeppe RE, Kombrabail M, Krishnamoorthy G, Chattopadhyay A. Membrane organization and dynamics of «inner pair» and «outer pair» tryptophan residues in gramicidin channels. J Phys Chem B, 2012, 116(36):11056-11064.

120. Hall AC, Suarez C, Hom-Choudhury A, Manu AN, Hall CD, Kirkovits GJ, Ghiriviga I. Cation transport by a redox-active synthetic ion channel. Org Biomol Chem 2003, 1(16):2973-2982.

121. von Haller PD, Yi E, Donohoe S, Vaughn K, Keller A, Nesvizhskii AI, Eng J, Li XJ, Goodlett DR, Aebersold R, Watts JD. The application of new software tools to quantitative protein profiling via isotope-coded affinity tag (ICAT) and tandem mass spectrometry: I. Statistically annotated datasets for peptide sequences and proteins identified via the application of ICAT and tandem mass spectrometry to proteins copurifying with T cell lipid rafts. Mol Cell Proteomics 2003, 2(7): 426-427.

122. von Haller PD, Yi E, Donohoe S, Vaughn K, Keller A, Nesvizhskii AI, Eng J, Li XJ, Goodlett DR, Aebersold R, Watts JD. The application of new software tools to quantitative protein profiling via isotope-coded affinity tag (ICAT) and tandem mass spectrometry: II. Evaluation of tandem mass spectrometry methodologies for large-scale protein analysis, and the application of statistical tools for data analysis and interpretation. Mol Cell Proteomics 2003a, 2(7):428-442.

123. Hamilton SL, Alvarez RM, Fill M, Hawkes MJ, Brush KL, Schilling WP, Stefani E. $\left[{ }^{3} \mathrm{H}\right] \mathrm{PN} 200-110$ and $\left[{ }^{3} \mathrm{H}\right]$ ryanodine binding and reconstitution of ion channel activity with skeletal muscle membranes. Anal Biochem 1989, 183(1):31-41.

124. Han D, Moon S, Kim Y, Min H, Kim Y. Characterization of the membrane proteome and N-glycoproteome in BV-2 mouse microglia by liquid chromatography-tandem mass spectrometry. BMC Genomics 2014, 15(95):1-17.

125. Han DK, Eng J, Zhou H, Aebersold R. Quantitative profiling of differentiationinduced microsomal proteins using isotope-coded affinity tags and mass spectrometry. Nat Biotechnol 2001, 19(10): 946-951.

126. Hao Y, Tang J, Wang K. Development of Automated Patch Clamp Assay for Evaluation of $\alpha 7$ Nicotinic Acetylcholine Receptor Agonists in Automated QPatch-16. Assay 
Drug Dev Technol 2015, 13(3):174-184.

127. Haqqani AS, Kelly JF, Stanimirovic DB. Quantitative protein profiling by mass spectrometry using isotope-coded affinity tags. Methods Mol Biol 2008, 439:225-240.

128. Hägglund P, Bunkenborg J, Maeda K, Finnie C, Svensson B. Identification of thioredoxin target disulfides using isotope-coded affinity tags. Methods Mol Biol 2014, 1072:677-685.

129. Herath KB, Zhong W, Yang J, Mahsut A, Rohm RJ, Shah V, Castro-Perez J, Zhou H, Attygalle AB, Kang L, Singh S, Johns DG, Cleary MA, Hubbard BK, Previs SF, Roddy TP. Determination of low levels of ${ }^{2} \mathrm{H}$-labeling using high-resolution mass spectrometry: application in studies of lipid flux and beyond. Rapid Commun Mass Spectrom 2014, 28(3):239244.

130. Hescheler J, Delpiano MA, Acker H, Pietruschka F. Ionic currents on type-I cells of the rabbit carotid body measured by voltage-clamp experiments and the effect of hypoxia. Brain Res 1989, 486(1):79-88.

131. Hirano T, Kidokoro Y, Ohmori H. Acetylcholine dose-response relation and the effect of cesium ions in the rat adrenal chromaffin cell under voltage clamp. Pflugers Arch 1987, 408(4):401-407.

132. Hochleitner EO, Kastner B, Fröhlich T, Schmidt A, Lührmann R, Arnold G, Lottspeich F. Protein stoichiometry of a multiprotein complex, the human spliceosomal U1 small nuclear ribonucleoprotein: absolute quantification using isotope-coded tags and mass spectrometry. J Biol Chem 2005, 280(4):2536-2542.

133. Hoffert JD, Chou CL, Knepper MA. Aquaporin-2 in the «-omics» era. J Biol Chem 2009, 284(22):14683-14687.

134. Hoffman RA, Long DD, Arndt RA, Roper LD. Voltage-clamp experiments on oxidized cholesterol membranes modified with excitability-inducing material and comparison with a model. Biochim Biophys Acta 1976, 455(3):780-795.

135. Holak TA, Engström A, Kraulis PJ, Lindeberg G, Bennich H, Jones TA, Gronenborn AM, Clore GM. The solution conformation of the antibacterial peptide cecropin A: a nuclear magnetic resonanceand dynamical simulated annealing study. Biochemistry 1988, 27(20):7620-7629.

136. Honda M, Kiyokawa J, Tabo M, Inoue T. Electrophysiological characterization of cardiomyocytes derived from human induced pluripotent stem cells. J Pharmacol Sci 2011, 117(3):149-159.

137. Hopper JT, Yu YT, Li D, Raymond A, Bostock M, Liko I, Mikhailov V, Laganowsky A, Benesch JL, Caffrey M, Nietlispach D, Robinson CV. Detergent-free mass spectrometry of membrane protein complexes. Nat Methods 2013, 10(12):1206-1208.

138. Horváth LI, Arias HR, Hankovszky HO, Hideg K, Barrantes FJ, Marsh D. Association of spin-labeled local anesthetics at the hydrophobic surface of acetylcholine receptor in native membranes from Torpedo marmorata. Biochemistry 1990, 29(37): 8707-8713.

139. Horvitz MA, Schoeller DA. Natural abundance deuterium and 18-oxygen effects on the precision of the doubly labeled water method. Amer J Physiol Endocrinol Metab 2001, 280(6): E965-E972.

140. Hu W, Lee KC, Cross TA. Tryptophans in membrane proteins: indole ring orientations and functional implications in the gramicidin channel. Biochemistry 1993, 32(27):7035-7047.

141. Huang DH, Walter R, Glickson JD, Krishna NR. Solution conformation of gramicidin S: An intramolecular nuclear Overhauser effect study. Proc Natd Acad Sci USA, 1981, 78(2):672-675.

142. Huege J, Goetze J, Dethloff F, Junker B, Kopka J. Quantification of stable isotope label in metabolites via mass spectrometry. Methods Mol Biol 2014, 1056:213- 
223.

143. Hung SC, Wang W, Chan SI, Chen HM. Membrane lysis by the antibacterial peptides cecropins B1 and B3: A spin-label electron spin resonance study on phospholipid bilayers. Biophys J 1999, 77(6): 3120-3133.

144. Ivanov VT, Miroshnikov AI, Snezhkova LG, Ovchinnikov YuA, Kulikov AV, Likhtenshtein GI. Use of electron-spin-resonance spectroscopy for studying the conformational states of peptides gramicidin S. Chem Nat Comp 1973, 9(1):82-87.

145. Ivanov VT, Sumskaya LV, Mikhaleva II, Laine MA, Ryabova ID, Ovchinnikov YuA. Synthesis of analogs of valinomycin and enniatine B containing charged, spin-labeled, or fluorescent groups. Chem Nat Comp 1974, 10(3): 350-358.

146. Ivanov II, Loktyushkin AV, Gus'kova RA, Vasil'ev NS, Fedorov GE, Rubin AB. Oxygen channels of erythrocyte membrane. Dokl Biochem Biophys 2007, 414:137-140.

147. Jackson TA, Muir DC. Mass-dependent and mass-independent variations in the isotope composition of mercury in a sediment core from a lake polluted by emissions from the combustion of coal. Sci Total Environ 2012, 417-418: 189-203.

148. Jajoo A, Dube A, Bharti S. $\mathrm{Mg}^{2+}$-induced lipid phase transition in thylakoid membranes is reversed by anions. Biochem Biophys Res Comm 1994, 202(3):17241730 .

149. Jochim N, Gerhard R, Just I, Pich A. Impact of clostridial glucosylating toxins on the proteome of colonic cells determined by isotope-coded protein labeling and LC-MALDI. Proteome Sci 2011, 9(48):1-12.

150. Jones CR, Sikakana CT, Hehir S, Kuo MC, Gibbons WA. The quantitation of nuclear Overhauser effect methods for total conformational analysis of peptides in solution. Application to gramicidin S. Biophys J 1978, 24(3):815-832.

151. Jones SM, Snell LD, Johnson KM. Characterization of the binding of radioligands to N-methyl-D-aspartate, phencyclidine, and glycine receptors in buffy coat membranes. J Pharmacol Methods 1989, 21(2):161-168.

152. Jung MY, Min DB. ESR study of the singlet oxygen quenching and protective activity of Trolox on the photodecomposition of riboflavin and lumiflavin in aqueous buffer solutions. J Food Sci 2009, 74(6):C449-C455.

153. Juvvadi P, Vunnam S, Merrifield EL, Boman HG, Merrifield RB. Hydrophobic effects on antibacterial and channel-forming properties of cecropin A-melittin hybrids. J Pept Sci 1996, 2(4):223-232.

154. Kanady JS, Mendoza-Cortes JL, Tsui EY, Nielsen RJ, Goddard WA, Agapie T. Oxygen atom transfer and oxidative water incorporation in cuboidal $\mathrm{Mn}_{3} \mathrm{MO}_{\mathrm{n}}$ complexes based on synthetic, isotopic labeling, and computational studies. J Amer Chem Soc 2013, 135(3):10731082.

155. Kapras V, Slavickova A, Stastna E, Vyklicky L, Vales K, Chodounska H. Synthesis of deuterium labeled NMDA receptor inhibitor - 20-Oxo-5 $\beta-\left[9,12,12-{ }^{2} \mathrm{H}_{3}\right]$ pregnan3a-yl-L-glutamyl 1-ester. Steroids 2012, 77(3):282-287.

156. Karle IL, Flippen-Anderson JL, Agarwalla S, Balaram P. Crystal structure of [Leu1]zervamicin, a membrane ion-channel peptide: implications for gating mechanisms. Proc Natl Acad Sci USA 1991, 88(12):5307-5311.

157. Karle IL, Flippen-Anderson JL, Agarwalla S, Balaram P. Conformation of the flexible bent helix of Leu1-zervamicin in crystal $\mathrm{C}$ and a possible gating action for ion passage. Biopolymers 1994, 34(6):721-735.

158. Kasazaki K, Yasukawa K, Sano H, Utsumi H. Non-invasive analysis of reactive oxygen species generated in $\mathrm{NH}_{4} \mathrm{OH}$-induced gastric lesions of rats using a $300 \mathrm{MHz}$ in 
vivo ESR technique. Free Radic Res 2003, 37(7):757-766.

159. Kedem O, Essig A. Isotope Flows and Flux Ratios in Biological Membranes. $J$ Gen Physiol 1965, 48(6):1047-1070.

160. Keleshian AM, Edeson RO, Liu GJ, Madsen BW. Evidence for cooperativity between nicotinic acetylcholine receptors in patch clamp records. Biophys $J$ 2000, 78(1):1-12.

161. Keller BU, Hedrich R. Patch clamp techniques to study ion channels from organelles. Methods Enzymol 1992, 207: 673-681.

162. Kellermann J, Lottspeich F. Isotope-coded protein label. Methods Mol Biol 2012, 893:143-153.

163. Kim YH, Cho K, Yun SH, Kim JY, Kwon KH, Yoo JS, Kim SI. Analysis of aromatic catabolic pathways in Pseudomonas putida KT 2440 using a combined proteomic approach: 2-DE/MS and cleavable isotope-coded affinity tag analysis. Proteomics 2006, 6(4):1301-1318.

164. Kirino Y, Ohkuma T, Shimizu H. Saturation transfer electron spin resonance study on the rotational diffusion of calcium- and magnesium-dependent adenosine triphosphatase in sarcoplasmic reticulum membranes. J Biochem 1978, 84(1):111-115.

165. Klein JS, Lewinson O. Bacterial ATP-driven transporters of transition metals: physiological roles, mechanisms of action, and roles in bacterial virulence. Metallomics 2011, 3(11):1098-1108.

166. Koulman A, Petras D, Narayana VK, Wang L, Volmer DA. Comparative highspeed profiling of carboxylic acid metabolite levels by differential isotope-coded MALDI mass spectrometry. Anal Chem 2009, 81(18):7544-7551.

167. Kozarova A, Sliskovic I, Mutus B, Simon ES, Andrews PC, Vacratsis PO. Identification of redox sensitive thiols of protein disulfide isomerase using isotope coded affinity technology and mass spectrometry. J Am Soc Mass Spectrom 2007, 18(2):260269.

168. Krishna NR, Agresti DG, Glickson JD, Walter R. Solution conformation of peptides by the intramolecular nuclear Overhauser effect experiment. Study of valinomycin-K ${ }^{+}$. Biophys J 1978, 24(3):791-814.

169. Kríz J, Makrlík E, Vanura P. NMR evidence of a valinomycin-proton complex. Biopolymers 2006, 81(2): 104-109.

170. Kuba K, Tanaka E, Kumamoto E, Minota S. Patch clamp experiments on nicotinic acetylcholine receptor-ion channels in bullfrog sympathetic ganglion cells. Pflugers Arch 1989, 414(2):105-112.

171. van Laere KJ, Sanabria-Bohórquez SM, Mozley DP, Burns DH, Hamill TG, Van Hecken A, De Lepeleire I, Koole M, Bormans G, de Hoon J, Depré M, Cerchio K, Plalcza J, Han L, Renger J, Hargreaves RJ, Iannone R. ${ }^{11}$ C-MK-8278 PET as a tool for pharmacodynamic brain occupancy of histamine 3 receptor inverse agonists. J Nucl Med 2014, 55(1): 65-72.

172. Laganowsky A, Reading E, Hopper JT, Robinson CV. Mass spectrometry of intact membrane protein complexes. Nat Protoc 2013, 8(4):639-651.

173. Lappin G, Seymour M. Addressing metabolite safety during first-in-man studies using ${ }^{14} \mathrm{C}$-labeled drug and accelerator mass spectrometry. Bioanalysis 2010, 2(7):1315-1324.

174. Lavi R, Sinyakov M, Samuni A, Shatz S, Friedmann H, Shainberg A, Breitbart H, Lubart R. ESR detection of ${ }^{1} \mathrm{O}_{2}$ reveals enhanced redox activity in illuminated cell cultures. Free Radic Res 2004, 38(9):893-902.

175. Lechene CP, Lee GY, Poczatek JC, Toner M, Biggers JD. 3D multiisotope imaging mass spectrometry reveals penetration of ${ }^{18} \mathrm{O}$-trehalose in mouse sperm nucleus. PLoS One 2012, 7(8):e42267.

176. Lee MC. Assessment of oxidative stress and antioxidant property using electron spin resonance (ESR) spectroscopy. J Clin Biochem Nutr 2013, 52(1):1-8. 
177. Li JH, DeSousa RC, Essig A. Kinetics of tracer flows and isotope interaction in an ion exchange membrane. J Membr Biol 1974, 19(1):93-104.

178. Li C, Hong Y, Tan YX, Zhou H, Ai JH, Li SJ, Zhang L, Xia QC, Wu JR, Wang HY, Zeng R. Accurate qualitative and quantitative proteomic analysis of clinical hepatocellu lar carcinoma using laser capture microdissection coupled with isotope-coded affinity tag and twodimensional liquid chromatography mass spectrometry. Mol Cell Proteomics 2004, 3(4):399409.

179. Li K, Hornshaw MP, van Minnen J, Smalla KH, Gundelfinger ED, Smit AB. Organelle proteomics of rat synaptic proteins: correlation-profiling by isotope-coded affinity tagging in conjunction with liquid chromatography-tandem mass spectrometry to reveal postsynaptic density specific proteins. J Proteome Res 2005, 4(3):725-733.

180. Liu H, Ponniah G, Neill A, Patel R, Andrien B. Identification and comparative quantitation of glycation by stable isotope labeling and LC-MS. J Chromatogr B Analyt Technol Biomed Life Sci 2014, 958:90-95.

181. Lohmann W, Tian PZ, Holz D, Schmehl W. Influence of metal ions on the transport of ascorbate across membranes. Int J Vitam Nutr Res 1986, 56(2):169-172.

182. López-Barneo J, Ortega-Sáenz B, García-Fernández M, Pardal R. Oxygen Sensing, Oxygen-sensitive Ion Channels and Mitochondrial Function in Arterial Chemoreceptors. Dev Cardiovasc Med 2004, 252: 361-373

183. Lovenberg T, Daly JW. Histrionicotoxins: effects on binding of radioligands for sodium, potassium, and calcium channels in brain membranes. Neurochem Res 1986, 11(11):1609-1621.

184. Malinovsky D, Vanhaecke F. Mass-independent isotope fractionation of heavy elements measured by MC-ICPMS: a unique probe in environmental sciences. Anal Bioanal Chem 2011, 400(6):1619-1624.

185. Manini P, Andreoli R, Sforza S, Dall'Asta C, Galaverna G, Mutti A, Niessen W M. Evaluation of Alternate Isotope-Coded Derivatization Assay (AIDA) in the LC-MS/MS analysis of aldehydes in exhaled breath condensate. J Chromatog B: Analyt Techn Biomed Life Sci 2010, 878(27):2616-2622.

186. Marassi FM, Opella SJ, Juvvadi P, Merrifield RB. Orientation of cecropin A helices in phospholipid bilayers determined by solid-state NMR spectroscopy. Biophys $J$ 1999, 77(6): 3152-3155.

187. Marinov BS. Ion channel redox model. J Mol Cell Cardiol 1991, 23(Suppl.1):5360.

188. Marnett LJ, Bienkowski MJ, Pagels WR. Oxygen 18 investigation of the prostaglandin synthetase-dependent co-oxidation of diphenylisobenzofuran. J Biol Chem 1979, 254(12):5077-5082.

189. Marsh D, Jost M, Peggion C, Toniolo C. Lipid chain-length dependence for incorporation of alamethicin in membranes: electron paramagnetic resonance studies on TOACspin labeled analogs. Biophys J 2007, 92(11):4002-4011.

190. Marsh D. Orientation and peptide-lipid interactions of alamethicin incorporated in phospholipid membranes: polarized infrared and spin-label EPR spectroscopy. Biochemistry 2009, 48(4):729-737.

191. Martín A, Szczupak B, Gómez-Vallejo V, Plaza S, Padró D, Cano A, Llop J. PET imaging of serotoninergic neurotransmission with $\left[{ }^{11} \mathrm{C}\right] \mathrm{DASB}$ and $\left[{ }^{18} \mathrm{~F}\right]$ altanserin after focal cerebral ischemia in rats. J Cereb Blood Flow Metab 2013, 33(12):1967-1975.

192. Martinez GR, Medeiros MH, Ravanat JL, Cadet J, Di Mascio P. [ ${ }^{18}$ O]-labeled singlet oxygen as a tool for mechanistic studies of 8-oxo-7,8-dihydroguanine oxidative damage: 
detection of spiroiminodihydantoin, imidazolone and oxazolone derivatives. Biol Chem 2002, 383(3-4):607-617.

193. Martínez CG, Jockusch S, Ruzzi M, Sartori E, Moscatelli A, Turro NJ, Buchachenko AL. Chemically induced dynamic electron polarization generated through the interaction between singlet molecular oxygen and nitroxide radicals. J Phys Chem A 2005, 109(45):10216-10221.

194. Marty MT, Zhang H, Cui W, Blankenship RE, Gross ML, Sligar SG. Native mass spectrometry characterization of intact nanodisc lipoprotein complexes. Anal Chem 2012, 84(21):8957-8960.

195. Marvizón JC, Skolnick P. Enhancement of t- $\left[{ }^{35}\right.$ S $]$ butylbicyclophosphorothionate and $\left[{ }^{3} \mathrm{H}\right]$ strychnine binding by monovalent anions reveals similarities between gammaaminobutyric acid- and glycine-gated chloride channels. J Neurochem 1988, 50(5):1632-1639.

196. Matalon S, Hardiman KM, Jain L, Eaton DC, Kotlikoff M, Eu JP, Sun J, Meissner G, Stamler JS. Regulation of ion channel structure and function by reactive oxygen-nitrogen species. Am J Physiol Lung Cell Mol Physiol 2003, 285(6):1184-1189.

197. Matsubayashi H, Inoue A, Amano T, Seki T, Nakata Y, Sasa M, Sakai N. Involvement of alpha7- and alpha4beta2-type postsynaptic nicotinic acetylcholine receptors in nicotine-induced excitation of dopaminergic neurons in the substantia nigra: a patch clamp and single-cell PCR study using acutely dissociated nigral neurons. Brain Res Mol Brain Res 2004, 129(1-2):1-7.

198. McCandless M, Nishiyama A, Petersen OH, Philpott HG. Mouse pancreatic acinar cells: voltage-clamp study of acetylcholine-evoked membrane current. J Physiol 1981, 318:57-71.

199. Mchaourab HS, Hyde JS, Feix JB. Aggregation state of spin-labeled cecropin AD in solution. Biochemistry 1993, 32(44):11895-11902.

200. Mchaourab HS, Hyde JS, Feix JB. Binding and state of aggregation of spinlabeled cecropin $\mathrm{AD}$ in phospholipid bilayers: effects of surface charge and fatty acyl chain length. Biochemistry 1994, 33(21):6691-6699.

201. McLeish MJ, Julin DA, Kirsch JF. Aspartate amino-transferase catalyzed oxygen exchange with solvent from oxygen-18-enriched alpha-ketoglutarate: evidence for slow exchange of enzyme-bound water. Biochemistry 1989, 28(9):3821-3825.

202. McMahon G, Saint-Cyr HF, Lechene C, Unkefer CJ. CN-secondary ions form by recombination as demonstrated using multi-isotope mass spectrometry of ${ }^{13} \mathrm{C}$ - and ${ }^{15} \mathrm{~N}$-labeled polyglycine. J Am Soc Mass Spectrom 2006, 17(8):1181-1187.

203. Meers P, Feigenson GW. Location and ion-binding of membrane-associated valinomycin, a proton nuclear magnetic resonance study. Biochim Biophys Acta 1988, 938(3): 469-482.

204. Melby ES, Soldat DJ, Barak P. Synthesis and detection of oxygen-18 labeled phosphate. PLoS One 2011, 6(4):e18420.

205. Methfessel C, Witzemann V, Takahashi T, Mishina M, Numa S, Sakmann B. Patch clamp measurements on Xenopus laevis oocytes: currents through endogenous channels and implanted acetylcholine receptor and sodium channels. Pflugers Arch 1986, 407(6):577-588.

206. Milone M, Hutchinson DO, Engel AG. Patch-clamp analysis of the properties of acetylcholine receptor channels at the normal human endplate. Muscle Nerve 1994, 17(12):1364-1369.

207. Milov AD, Tsvetkov YD, Gorbunova EY, Mustaeva LG, Ovchinnikova TV, Raap J. Self-aggregation properties of spin-labeled zervamicin IIA as studied by PELDOR spectroscopy. Biopolymers 2002, 64(6):328-336.

208. Milov AD, Samoilova RI, Shubin AA, Gorbunova EY, Mustaeva LG, Ovchinnikova TV, Raap J, Tsvetkov YD. Self-Aggregation and Orientation of the Ion Channel- 
Forming Zervamicin IIA in the Membranes of ePC. Appl Magn Res 2010, 38(1):75-84.

209. Moan J, Wold E. Detection of singlet oxygen production by ESR. Nature 1979, 279(5712):450-451.

210. Moerlein SM, Gaehle GG, Lechner KR, Bera RK, Welch MJ. Automated production of oxygen-15 labeled butanol for PET measurement of regional cerebral blood flow. Appl Radiat Isot 1993, 44(9):1213-1218.

211. Molloy MP, Donohoe S, Brzezinski EE, Kilby GW, Stevenson TI, Baker JD, Goodlett DR, Gage DA. Large-scale evaluation of quantitative reproducibility and proteome coverage using acid cleavableisotope coded affinity tag mass spectrometry for proteomic profiling. Proteomics 2005, 5(5):1204-1208.

212. Morgner N, Montenegro F, Barrera NP, Robinson CV. Mass spectrometry - from peripheral proteins to membrane motors. J Mol Biol 2012, 423(1):1-13.

213. Moulder R, Filén JJ, Salmi J, Katajamaa M, Nevalainen OS, Oresic M, Aittokallio T, Lahesmaa R, Nyman TA. A comparative evaluation of software for the analysis of liquid chromatography-tandem mass spectrometry data from isotope coded affinity tag experiments. Proteomics 2005, 5(11):2748-2760.

214. Muñiz JJ, Pottosin II, Sandoval L. Patch-clamp study of vascular plant chloroplasts: ion channels and photocurrents. J Bioenerg Biomembr 1995, 27(2):249-258.

215. Murphy RC, Clay KL. Preparation of labeled molecules by exchange with oxygen-18 water. Methods Enzymol 1990, 193:338-348.

216. Negash S, Yao Q, Sun H, Li J, Bigelow DJ, Squier TC. Phospholamban remains associated with the $\mathrm{Ca}^{2+}$ - and $\mathrm{Mg}^{2+}$-dependent ATPase following phosphorylation by cAMPdependent protein kinase. Biochem J 2000, 351(1):195-205.

217. Nelson ID, Huddart H. The nature of the acetylcholine receptor in a Buccinum proboscis muscle examined by the sucrose-gap voltage clamp technique. Gen Pharmacol 1992, 23(3):317-323.

218. Nelson KJ, Day AE, Zeng BB, King SB, Poole LB. Isotope-coded, iodoacetamide-based reagent to determine individual cysteine $\mathrm{pK}(\mathrm{a})$ values by matrix-assisted laser desorption/ionization time-of-flight mass spectrometry. Anal Biochem 2008, 375(2):187195.

219. Nesbitt DM, Berg SP. Proton involvement with the light-induced hindrance of spin label motion in the lumen of spinach thylakoids. Biochim Biophys Acta 1980, 593(2):353-361.

220. Niles R, Witkowska HE, Allen S, Hall SC, Fisher SJ, Hardt M. Acidcatalyzed oxygen-18 labeling of peptides. Anal Chem 2009, 81(7):2804-2809.

221. Nooney JM, Peters JA, Lambert JJ. A patch clamp study of the nicotinic acetylcholine receptor of bovine adreno-medullary chromaffin cells in culture. J Physiol 1992, 455:503-527.

222. Ogiso T, Iwaki M, Mori K. Fluidity of human erythrocyte membrane and effect of chlorpromazine on fluidity and phase separation of membrane. Biochim Biophys Acta 1981, 649(2):325-335.

223. Ogrel A, Bloemhoff W, Lugtenburg J, Raap J. Total synthesis of zervamicin IIB and its deuterium-labelled analogues. J Pept Sci 1997, 3(3):193-208.

224. Oh D, Shin SY, Kang JH, Hahm KS, Kim KL, Kim Y. NMR structural characterization of cecropin A(1-8)-magainin 2(1-12) and cecropin A (1-8)-melittin (1-12) hybrid peptides. J Pept Res 1999, 53(5):578-589.

225. Ohno T, Hirata T. Simultaneous determination of massdependent isotopic fractionation and radiogenic isotope variation of strontium in geochemical 
samples by multiple collector-ICP-mass spectrometry. Anal Sci 2007, 23(11):1275-1280.

226. Ohno T, Hirata T. Determination of mass-dependent isotopic fractionation of cerium and neodymium in geochemical samples by MC-ICPMS. Anal Sci 2013, 29(1):47-53.

227. Otsubo T, Yamaguchi S, Okumura M, Shirahata M. Differential Expression of Oxygen Sensitivity in Voltage-Dependent K Channels in Inbred Strains of Mice. Adv Exp Med \& Biol 2006, 580:209-214.

228. Ovchinnikova TV, Shenkarev ZO, Yakimenko ZA, Svishcheva NV, Tagaev AA, Skladnev DA, Arseniev AS. Biosynthetic uniform ${ }^{13} \mathrm{C},{ }^{15} \mathrm{~N}$-labelling of zervamicin IIB. Complete ${ }^{13} \mathrm{C}$ and ${ }^{15} \mathrm{~N}$ NMR assignment. J Pept Sci 2003, 9(11-12):817-826.

229. Ovchinnikova TV, Levitskaya NG, Voskresenskaya OG, Yakimenko ZA, Tagaev AA, Ovchinnikova AY, Murashev AN, Kamenskii AA. Neuroleptic properties of the ionchannel-forming peptaibol zervamicin: locomotor activity and behavioral effects. Chem Biodivers 2007, 4(6):1374-1387.

230. Pan Y, Ye M, Zheng H, Cheng K, Sun Z, Liu F, Liu J, Wang K, Qin H, Zou H. Trypsin-catalyzed N-terminal labeling of peptides with stable isotope-coded affinity tags for proteome analysis. Anal Chem 2014, 86(2):1170-1177.

231. Pannkuk EL, McGuire LP, Gilmore DF, Savary BJ, Risch TS. Glycerophospholipid analysis of eastern red bat (Lasiurus borealis) hair by electrospray ionization tandem mass spectrometry. J Chem Ecol 2014, 40(3):227-235.

232. Parker CH, Morgan CR, Rand KD, Engen JR, Jorgenson JW, Stafford DW. A Conformational Investigation of Propeptide Binding to the Integral Membrane Protein $\gamma$ Glutamyl Carboxylase Using Nanodisc Hydrogen Exchange Mass Spectrometry. Biochemistry 2014, 53(9):1511-1520.

233. Pennington AJ, Martin RJ. A patch-clamp study of acetylcholine-activated ion channels in Ascaris suum muscle. J Exp Biol 1990, 154:201-221.

234. Perozo E, Kloda A, Cortes DM, Martinac B. Site-Directed Spin-Labeling Analysis of Reconstituted Mscl in the Closed State. J Gen Physiol 2001, 118(2):193-206.

235. Petrotchenko EV, Yamaguchi N, Pasek DA, Borchers CH, Meissner G. Mass spectrometric analysis and mutagenesis predict involvement of multiple cysteines in redox regulation of the skeletal muscle ryanodine receptor ion channel complex. Res Rep Biol 2011, 2:13-21.

236. Pettelkau J, Thondorf I, Theisgen S, Lilie H, Schröder T, Arlt C, Ihling CH, Sinz A. Structural analysis of guanylyl cyclase-activating protein-2 (GCAP-2) homodimer by stable isotope-labeling, chemical cross-linking, and mass spectrometry. J Am Soc Mass Spectr 2013, 24(12):1969-1979.

237. Pickett WC, Murphy RC. Enzymatic preparation of carboxyl oxygen-18 labeled prostaglandin F2 alpha and utility for quantitative mass spectrometry. Anal Biochem 1981, 111(1):115-121.

238. Pike VW, Halldin C, Crouzel C, Barré L, Nutt DJ, Osman S, Shah F, Turton DR, Waters SL. Radioligands for PET studies of central benzodiazepine receptors and PK (peripheral benzodiazepine) binding sites-current status. Nucl Med Biol 1993, 20(40):503-525.

239. Pisani A, Bonsi P, Catania MV, Giuffrida R, Morari M, Marti M, Centonze D, Bernardi G, Kingston AE, Calabresi P. Metabotropic glutamate 2 receptors modulate synaptic inputs and calcium signals in striatal cholinergic interneurons. J Neurosci 2002, 22(14):61766185

240. de Planque MR, Greathouse DV, Koeppe RE, Schäfer H, Marsh D, Killian JA. Influence of lipid/peptide hydrophobic mismatch on the thickness of diacylphosphatidylcholine bilayers. A ${ }^{2} \mathrm{H}$ NMR and ESR study using designed transmembrane alpha-helical peptides and gramicidin A. Biochemistry 1998, 37(26):9333-9345.

241. Ponnusamy E, Fiat D, Jones CR. Oxygen-18 isotope labeling and its effect on 
carbon-13 chemical shifts of the peptide bond. Int J Pept Prot Res 1986, 28(5):542-545.

242. Popova AM, Williamson JR. Quantitative analysis of rRNA modifications using stable isotope labeling and mass spectrometry. J Am Chem Soc 2014, 136(5):2058-2069.

243. Pottosin II, Schönknecht G. Patch clamp study of the voltage-dependent anion channel in the thylakoid membrane. J Membr Biol 1995, 148(2):143-156.

244. Prokai L, Zharikova AD, Stevens SM. Effect of chronic morphine exposure on the synaptic plasma-membrane subproteome of rats: a quantitative protein profiling study based on isotope-coded affinity tags and liquid chromatography/mass spectrometry. J Mass Spectrom 2005, 40(2):169-175.

245. Publicover SJ, Barratt CL. Chloride channels join the sperm «channelome». $J$ Physiol 2012, 590(11):2553-2554.

246. Pulagam LP, Steinhoff HJ. Acidic pH-induced membrane insertion of colicin A into E. coli natural lipids probed by site-directed spin labeling. J Mol Biol 2013, 425(10):17821794.

247. Puppi A, Nánási P, Dely M. Influence of the redox-state potential of biophase on electrically stimulated skeletal muscles (myographic and voltage-clamp analysis). Acta Physiol Hung 1991, 77(1):33-41.

248. Puzo G, Schram KH, McCloskey JA. Incorporation of oxygen-18 into nucleosides and bases. Nucleic Acids Res 1977, 4(6):2075-2081.

249. Qi H, Dong XF, Zhao YP, Li N, Fu H, Feng DD, Liu L, Yu CX. ROS production in homogenate from the body wall of sea cucumber Stichopus japonicus under UVA irradiation: ESR spin-trapping study. Food Chem 2016, 192:358-362.

250. Qian WJ, Petritis BO, Nicora CD, Smith RD. Trypsin-catalyzed oxygen18 labeling for quantitative proteomics. Methods Mol Biol 2011, 753:43-54.

251. Qin PZ, Feigon J, Hubbell WL. Site-directed spin labeling studies reveal solution conformational changes in a GAAA tetraloop receptor upon $\mathrm{Mg}^{2+}$-dependent docking of a GAAA tetraloop. J Mol Biol 2005, 351(1):1-8

252. Qu J, Jusko WJ, Straubinger RM. Utility of cleavable isotope-coded affinitytagged reagents for quantification of low-copy proteins induced by methylprednisolone using liquid chromatography tandem mass spectrometry. Anal Chem 2006, 78(13):4543-4542.

253. Rainczuk A, Condina M, Pelzing M, Dolman S, Rao J, Fairweather N, Jobling T, Stephens AN. The utility of isotope-coded protein labeling for prioritization of proteins found in ovarian cancer patient urine. J Proteome Res 2013, 12(9):4074-4088.

254. Rauh JJ, Benner E, Schnee ME, Cordova D, Holyoke CW, Howard MH, Bai D, Buckingham SD, Hutton ML, Hamon A, Roush RT, Sattelle DB. Effects of [ $\left.{ }^{3} \mathrm{H}\right]-\mathrm{BIDN}$, a novel bicyclic dinitrile radioligand for GABA-gated chloride channels of insects and vertebrates. $\mathrm{Br} \mathrm{J}$ Pharmacol 1997, 121(7):1496-1505.

255. Re L, Corneli C, Sturani E, Paolucci G, Rossini F, León OS, Martínez G, Bordicchia M, Tomassetti Q. Effects of Hypericum extract on the acetylcholine release: a loose patch clamp approach. Pharmac Res 2003, 48(1):55-60.

256. Rezayat SM, Boushehri SV, Salmanian B, Omidvari AH, Tarighat S, Esmaeili S, Sarkar S, Amirshahi N, Alyautdin RN, Orlova MA, Trushkov IV, Buchachenko AL, Liu KC, Kuznetsov DA. The porphyrin-fullerene nanoparticles to promote the ATP overproduction in myocardium: ${ }^{25} \mathrm{Mg}^{2+}$-magnetic isotope effect. Eur J Med Chem 2009, 44(4):1554-1569.

257. Richardson ES, Xiao Y-F. Electrophysiology of Single Cardiomyocytes: Patch Clamp and Other Recording Methods. In Cardiac Electrophysiology Methods and Models. Edited by Sigg DC, Iaizzo PA, Xiao Y-F, He B. New York, Dordrecht, Heidelberg, London: Springer; 2010:329-348. 
258. Risley JM., Van Etten RL. Mechanistic studies utilizing oxygen-18 analyzed by carbon-13 and nitrogen-15 nuclear magnetic resonance spectroscopy. Methods Enzymol 1989, 177:376-389.

259. Robertson AP, Buxton SK, Martin RJ. Whole-cell patch-clamp recording of nicotinic acetylcholine receptors in adult Brugia malayi muscle. Parasitol Int 2013, 62(6):616618.

260. Rosen GM, Abou Donia MB, Yeh JZ, Menzel DB. Spin labeled acetylcholine analogs: studies of cholinergic receptor. Res Commun Chem Path and Pharm 1975, 12(2):317329.

261. Rosenberg S, Kirsch JF. Oxygen-18 leaving group kinetic isotope effects on the hydrolysis of nitrophenyl glycosides. 1. Beta-galactosidease-catalyzed hydrolysis. Biochemistry 1981, 20(11):3189-3196.

262. Rosenberg S, Kirsch JF. Oxygen-18 leaving group kinetic isotope effects on the hydrolysis of nitrophenyl glycosides. 2. Lysozyme and beta-glucosidase: acid and alkaline hydrolysis. Biochemistry 1981a, 20(11):3196-3204.

263. Rubin JG, Soderlund DM. Binding of $\left[{ }^{3} \mathrm{H}\right]$ batrachotoxinin A-20-alpha-benzoate and $\left[{ }^{3} \mathrm{H}\right]$ saxitoxin to receptor sites associated with sodium channels in trout brain synaptoneurosomes. Comp Biochem Physiol C 1993, 105(2):231-238.

264. Rubovszky B, Szentmiklósi AJ, Márián T, Cseppento A, Gesztelyi R, Székely A, Fórizs F, Gáspár R, Trón L, Krasznai Z. Comparative pharmacological studies on the $\mathrm{A}_{2}$ adenosine receptor agonist 5'-n-ethyl-carboxamido-adenosine and its $\mathrm{F}^{19}$ isotope labelled derivative. J Pharmacol Sci 2003, 93(3):356-363.

265. Ruseva S, Lozanov V, Markova P, Girchev R, Mitev V. In vivo investigation of homocysteine metabolism to polyamines by high resolution accurate mass spectrometry and stable isotope labeling. Anal Biochem 2014, 457:38-47.

266. Sachs F, Lecar H. Acetylcholine-induced current fluctuations in tissue-cultured muscle cells under voltage clamp. Biophys J 1977, 17(2):129-143.

267. Saita M, Kobayashi K, Yoshino F, Hase H, Nonami T, Kimoto K, Lee MC. ESR investigation of ROS generated by $\mathrm{H}_{2} \mathrm{O}_{2}$ bleaching with $\mathrm{TiO}_{2}$ coated HAp. Dent Mater J 2012, 31(3):458-464.

268. Salouros H, Sutton GJ, Howes J, Hibbert DB, Collins M. Measurement of stable isotope ratios in methylamphetamine: a link to its precursor source. Anal Chem 2013, 85(19):9400-9408.

269. Salehpour M, Forsgard N, Possnert G. FemtoMolar measurements using accelerator mass spectrometry. Rapid Comm Mass Spec 2009, 23(5):557-563.

270. Sano T, Iida Y, Hiraoka M. Action of acetylcholine on the Purkinje fiber studied by voltage clamp technique. J Physiol 1970, 20(2):155-166.

271. Sansom MS, Balaram P, Karle IL. Ion channel formation by zervamicin-IIB. A molecular modelling study. Eur Biophys J 1993, 21(6):369-383.

272. Sawada T, Yoshino F, Kimoto K, Takahashi Y, Shibata T, Hamada N, Sawada T, Toyoda M, Lee M. ESR detection of ROS generated by $\mathrm{TiO}_{2}$ coated with fluoridated apatite. $J$ Dent Res 2010, 89(8):848-853.

273. Schaich KM, Karel M. Free radical reactions of peroxidizing lipids with amino acids and proteins: an ESR study. Lipids 1976, 11(5):392-400.

274. Schliep M, Crossett B, Willows RD, Chen M. ${ }^{18} \mathrm{O}$ labeling of chlorophyll d in Acaryochloris marina reveals that chlorophyll a and molecular oxygen are precursors. $J$ Biol Chem 2010, 285(37):28450-28456.

275. Schmidt C, Grønborg M, Deckert J, Bessonov S, Conrad T, Lührmann R, Urlaub H. Mass spectrometry-based relative quantification of proteins in precatalytic and catalytically active spliceosomes by metabolic labeling (SILAC), chemical labeling (iTRAQ), and label-free 
spectral count. RNA 2014, 20(3):406-420.

276. Schneiter R, Brügger B, Sandhoff R, Zellnig G, Leber A, Lampl M, Athenstaedt K, Hrastnik C, Eder S, Daum G, Paltauf F, Wieland FT, Kohlwein SD. Electrospray ionization tandem mass spectrometry (ESI-MS/MS) analysis of the lipid molecular species composition of yeast subcellular membranes reveals acyl chain-based sorting/remodeling of distinct molecular species en route to the plasma membrane. J Cell Biol 1999, 146(4):741-754.

277. Schön P, Degefa TH, Asaftei S, Meyer WW. Charge propagation in «ion channel sensors» based on protein-modified electrodes and redoxmarker ions. J Am Chem Soc 2005, 127(32):11486-11496.

278. Schrimpf SP, Meskenaite V, Brunner E, Rutishauser D, Walther P, Eng J, Aebersold R, Sonderegger P. Proteomic analysis of synaptosomes using isotope-coded affinity tags and mass spectrometry. Proteomics 2005, 5(10):2531-2541.

279. Schroder R, Christensen M, Anson B, Sunesen M. Electrophysiological properties of iCell cardiomyocytes obtained by automated patch clamp on QPatch. J Pharm Toxic Methods 2012, 66(2):178.

280. Sentjurc M, Stalc A, Zupancic AO. An ESR study of the postsynatpic membrane acetylcholinesterase of Torpedo marmorata electric organ. Mol Cel Biochem 1976, 13(3):137139.

281. Seo J, Yoon HJ, Shin SK. Quantification of tryptic peptides in quadrupole ion trap using high-mass signals derived from isotope-coded $\mathrm{N}$-acetyl dipeptide tags. J Am Soc Mass Spectrom 2007, 22(9):1668-1677.

282. Sethuraman M, Clavreul N, Huang H, McComb ME, Costello CE, Cohen RA. Quantification of oxidative posttranslational modifications of cysteine thiols of p21ras associated with redox modulation of activity using isotope-coded affinity tags and mass spectrometry. Free Radic Biol Med 2007, 42(6):823-829.

283. Sha XM, Tu ZC, Wang H, Huang T, Duan DL, He N, Li DJ, Xiao H. Gelatin quantification by oxygen-18 labeling and liquid chromatography-high-resolution mass spectrometry. J Agric Food Chem 2014, 62(49):11840-11853.

284. Shattock MJ, Matsuura H. Measurement of $\mathrm{Na}^{+}-\mathrm{K}^{+}$pump current in isolated rabbit ventricular myocytes using the whole-cell voltage-clamp technique. Inhibition of the pump by oxidant stress. Circ Res 1993, 72(1):91-101.

285. Shen PT, Hsu JL, Chen SH. Dimethyl isotope-coded affinity selection for the analysis of free and blocked N-termini of proteins using LC-MS/MS. Anal Chem 2007, 79(24):9520-9530.

286. Shenkarev ZO, Balashova TA, Efremov RG, Yakimenko ZA, Ovchinnikova TV, Raap J, Arseniev AS. Spatial structure of zervamicin IIB bound to DPC micelles: implications for voltage-gating. Biophys J 2002, 82(2):762-771.

287. Shetab Boushehri SV, Ostad SN, Sarkar S, Kuznetsov DA, Buchachenko AL, Orlova MA, Minaii B, Kebriaeezadeh A, Rezayat SM. The $\mathrm{C}_{60}$-fullerene porphyrin adducts for prevention of the doxorubicin-induced acute cardiotoxicity in rat myocardial cells. Acta Med Iran 2010, 48(5):342-350.

288. Shiio Y, Aebersold R. Quantitative proteome analysis using isotope-coded affinity tags and mass spectrometry. Nat Protoc 2006, 1(1):139-145.

289. Shin YK, Levinthal C, Levinthal F, Hubbell WL. Colicin E1 binding to membranes: time-resolved studies of spin-labeled mutants. Science 1993, 259(5097):960-963.

290. Simon SA, Baggett HC. Identification of muscarinic acetylcholine receptors in isolated canine lingual epithelia via voltage clamp measurements. Arch Oral Biol 1992, 37(9):685-690. 
291. Sipos D, Chandrasekhar K, Arvidsson K, Engström A, Ehrenberg A. Twodimensional proton-NMR studies on a hybrid peptide between cecropin A and melittin. Resonance assignments and secondary structure. Eur J Biochem 1991, 199(2):285-291.

292. Sipos D, Andersson M, Ehrenberg A. The structure of the mammalian antibacterial peptide cecropin P1 in solution, determined by proton-NMR. Eur J Biochem 1992, 209(1):163-169.

293. Sleep JA, Hackney DD, Boyer PD. Characterization of phosphate oxygen exchange reactions catalyzed by myosin through measurement of the distribution of 18-O-labeled species. J Biol Chem 1978, 253(15):5235-5238.

294. Smolka M, Zhou H, Aebersold R. Quantitative protein profiling using twodimensional gel electrophoresis, isotope-coded affinity tag labeling, and mass spectrometry. Mol Cell Proteomics 2002, 1(1):19-29.

295. Song YZ, An J, Jiang L. ESR evidence of the photo-generation of free radicals $\left(\mathrm{GDHB}^{*-}, \mathrm{O}_{2}{ }^{{ }^{*}}\right)$ and singlet oxygen $\left({ }^{1} \mathrm{O}_{2}\right)$ by 15-deacetyl-13-glycine-substituted hypocrellin $\mathrm{B}$. Biochim Biophys Acta 1999, 1472(1-2):307-313.

296. Souda P, Ryan CM, Cramer WA, Whitelegge J. Profiling of integral membrane proteins and their post translational modifications using high-resolution mass spectrometry. Methods 2011, 55(4):330-336.

297. Sørensen P. Changes in the viscosity of the plasma membrane of flounder (Platichthys flesus L.) erythrocyte induced by varying the content of membrane cholesterol or by benzyl alcohol. Correlation of the activity of the intrinsic $\mathrm{Mg}^{2+}$-ATPase and the viscosity. Comp Biochem Physiol B 1987, 87(1):109-116.

298. Sparbier K, Lange C, Jung J, Wieser A, Schubert S, Kostrzewa M. MALDI biotyper-based rapid resistance detection by stable-isotope labeling. J Clin Microbiol 2013, 51(11):3741-3748.

299. Staes A, Demol H, Van Damme J, Martens L, Vandekerckhove J, Gevaert K. Global differential non-gel proteomics by quantitative and stable labeling of tryptic peptides withoxygen-18. J Proteome Res 2004, 3(4):786-791.

300. Steinhauser ML, Bailey AP, Senyo SE, Guillermier C, Perlstein TS, Gould AP, Lee RT, Lechene CP. Multi-isotope imaging mass spectrometry quantifies stem cell division and metabolism. Nature 2012, 481(7382):516-519.

301. Steinhauser ML, Lechene CP. Quantitative imaging of subcellular metabolism with stable isotopes and multi-isotope imaging mass spectrometry. Semin Cell Dev Biol 2013, 24(8-9):661-667.

302. Stempel KE, Boyer PD. Refinements in oxygen-18 methodology for the study of phosphorylation mechanisms. Methods Enzymol 1986, 126:618-639.

303. Stingl C, Söderquist M, Karlsson O, Borén M, Luider TM. Uncovering effects of ex vivo protease activity during proteomics and peptidomics sample extraction in rat brain tissue by oxygen-18 labeling. J Proteome Res 2014, 13(6):2807-2817.

304. Stoelzle S, Haythornthwaite A, Kettenhofen R, Kolossov E, Bohlen H, George M, Brüggemann A, Fertig N. Automated patch clamp on mESC-derived cardiomyocytes for cardiotoxicity prediction. J Biomol Screen 2011, 16(8):910-916.

305. Subramanyam R, Bucelewicz WM, Hoop B, Jones SC. A system for oxygen-15 labeled blood for medical applications. Int J Appl Radiat Isot 1977, 28(1-2):21-24.

306. Sun T, Bao H. Thermal-gradient-induced non-mass-dependent isotope fractionation. Rapid Commun Mass Spectrom 2011, 25(6):765-773.

307. Sundberg SA, Hubbell WL. Investigation of surface potential asymmetry in phospholipid vesicles by a spin label relaxation method. Biophys $J$ 1986, 49(2):553-562.

308. Takeuchi Y, Ohnishi SI, Ishinaga M, Kito M. Spin-labeling of Escherichia coli membrane by enzymatic synthesis of phosphatidylglycerol and divalent cation-induced 
interaction of phosphatidylglycerol with membrane proteins. Biochim Biophys Acta 1978, 506(1):54-63.

309. Takeuchi Y, Ohnishi SI, Ishinaga M, Kito M. Dynamic states of phospholipids in Escherichia coli B membrane. Electron spin resonance studies with biosynthetically generated phospholipid spin labels. Biochim Biophys Acta 1981, 646(1):119-125.

310. Takeyasu K, Udgaonkar JB, Hess GP. Acetylcholine receptor: evidence for a voltage-dependent regulatory site for acetylcholine. Chemical kinetic measurements in membrane vesicles using a voltage clamp. Biochemistry 1983, 22(25):5973-5978.

311. Tam EM, Morrison CJ, Wu YI, Stack MS, Overall CM. Membrane protease proteomics: Isotope-coded affinity tag MS identification of undescribed MT1-matrix metalloproteinase substrates. Proc Natl Acad Sci USA 2004, 101(18):6917-6922.

312. Tang B, Li Y, Zhao L, Yuan S, Wang Z, Li B, Chen Q. Stable isotope dimethyl labeling combined with LTQ mass spectrometric detection, a quantitative proteomics technology used in liver cancer research. Biomed Rep 2013, 1(4):549554.

313. Thominiaux C, de Bruin B, Bramoullé Y, Hinnen F, Demphel S, Valette H, Bottlaender M, Besret L, Kassiou M, Dollé F. Radiosynthesis of (E)-N-(2- $\left[{ }^{11} \mathrm{C}\right]$ methoxybenzyl)3-phenyl-acrylamidine, a novel subnanomolar NR2B subtype-selective NMDA receptor antagonist. Appl Radiat Isot 2006, 64(3):348-354.

314. Tian G, Berry JA, Klinman JP. Oxygen-18 kinetic isotope effects in the dopamine beta-monooxygenase reaction: evidence for a new chemical mechanism in non-heme metallomonooxygenases. Biochemistry 1994, 33(1):226-234.

315. Tikhonov A, Khomutov G, Ruuge E. Electron paramagnetic study of electron transport in photosynthetic systems. X. Effect of magnesium ions on the structural state of thylakoid membranes and the kinetics of electron transport between the two photosystems in bean chloroplasts. Mol Biol 1980, 14(5):1065-1079.

316. Todd AP, Cong J, Levinthal F, Levinthal C, Hubbell WL. Site-directed mutagenesis of colicin E1 provides specific attachment sites for spin labels whose spectra are sensitive to local conformation. Proteins 1989, 6(3):294-305.

317. Torde RG, Therrien AJ, Shortreed MR, Smith LM, Lamos SM. Multiplexed analysis of cage and cage free chicken egg fatty acids using stable isotope labeling and mass spectrometry. Molecules 2013, 18(12):14977-14988.

318. Toyo'oka T. LC-MS determination of bioactive molecules based upon stable isotope-coded derivatization method. J Pharm Biomed Anal 2012, 69:174-184.

319. Trompelt K, Steinbeck J, Terashima M, Hippler M. A New Approach for the Comparative Analysis of Multiprotein Complexes Based on ${ }^{15} \mathrm{~N}$ Metabolic Labeling and Quantitative Mass Spectrometry. J Vis Exp 2014, 85:e51103.

320. Tsikolia M, Hall AC, Suarez C, Nylander ZO, Wardlaw SM, Gibson ME, Valentine KL, Onyewadume LN, Ahove DA, Woodbury M, Mongare MM, Hall CD, Wang Z, Draghici B, Katritzky AR. Synthesis and characterization of a redox-active ion channel supporting cation flux in lipid bilayers. Org Biomol Chem 2009, 7(18):3862-3870.

321. Tsumoto H, Murata C, Miyata N, Kohda K, Taguchi R. Efficient identification and quantification of proteins using isotope-coded 1-(6-methylnicotinoyloxy)succinimides by matrix-assisted laser desorption/ionization time-of-flight mass spectrometry. Rapid Commun Mass Spectrom 2007, 21(23):3815-3824.

322. Turecek F. Mass spectrometry in coupling with affinity capture-release and isotope-coded affinity tags for quantitative protein analysis. J Mass Spectrom 2002, 37(1):1-14.

323. Turtoi A, Mazzucchelli GD, De Pauw E. Isotope coded protein label 
quantification of serum proteins--comparison with the label-free LC-MS and validation using the MRM approach. Talanta 2010, 80(4):1487-1495.

324. Vaughn CP, Crockett DK, Lim MS, Elenitoba-Johnson KS. Analytical characteristics of cleavable isotope-coded affinity tag-LC-tandem mass spectrometry for quantitative proteomic studies. J Mol Diagn 2006, 8(4):513-520.

325. van Veghel D, Cleynhens J, Pearce LV, DeAndrea-Lazarus IA, Blumberg PM, Van Laere K, Verbruggen A, Bormans G. New transient receptor potential vanilloid subfamily member 1 positron emission tomography radioligands: synthesis, radiolabeling, and preclinical evaluation. ACS Chem Neurosci 2013, 4(4):624-634.

326. Viret J, Leterrier F. A spin label study of rat brain membranes. Effects of temperature and divalent cations. Biochim Biophys Acta 1976, 436(4):811-824.

327. Vogt A, Fuerholzner B, Kinkl N, Boldt K, Ueffing M. Isotope coded protein labeling coupled immuno-precipitation (ICPL-IP): a novel approach for quantitative protein complex analysis from native tissue. Mol Cell Proteomics 2013, 12(5):1395-1406.

328. Voigt N, Makary S, Nattel S, Dobrev D. Voltage-clamp-based methods for the detection of constitutively active acetylcholine-gated $\mathrm{I}(\mathrm{K}, \mathrm{ACh})$ channels in the diseased heart. Methods Enzymol 2010, 484:653-675.

329. Waas M, Bhattacharya S, Chuppa S, Wu X, Jensen DR, Omasits U, Wollscheid B, Volkman BF, Noon KR, Gundry RL. Combine and conquer: surfactants, solvents, and chaotropes for robust mass spectrometry based analyses of membrane proteins. Anal Chem 2014, 86(3):1551-1559.

330. Wachtel RE, Wilson WA. Use of the single electrode voltage clamp to perform noise and relaxation studies of acetylcholine-activated channels in Aplysia neurons. $J$ Neurosci Methods 1981, 4(1):87-103.

331. Wang HH, Yeh JZ, Narahashi T. Interaction of spin-labeled local anesthetics with the sodium channel of squid axon membranes. J Membr Biol 1982, 66(3):227-233.

332. Wang XM, Qi Y, Sun CW, Zhong GG, Jiang Y, Qiu YH. Single calcium channel analysis and electron spin resonance (ESR) spectral study on the myocardial effects of ginsenoside Rb2. China Journal of Chinese materia medica 1994, 19(10): 621-624.

333. Wang Z. Role of redox state in modulation of ion channel function by fatty acids and phospholipids. Br J Pharmacol 2003, 139(4):681-683.

334. Wang F, Qin L, Wong P, Gao J. Effects of lysine methylation on gramicidin channel folding in lipid membranes. Biopolymers 2013, 100(6):656-661.

335. Wang C, Wu Z, Yuan J, Wang B, Zhang P, Zhang Y, Wang Z, Huang L. Simplified quantitative glycomics using the stable isotope label Girard's reagent $p$ by electrospray ionization mass spectrometry. J Proteome Res 2014, 13(2):372-384.

336. West JB. Studies of pulmonary and cardiac function using short-lived isotopes oxygen-15, nitrogen-13 and carbon-11. Prog At Med 1968, 2:39-64.

337. Woody CD, Gruen E. Acetylcholine reduces net outward currents measured in vivo with single electrode voltage clamptechniques in neurons of the motor cortex of cats. Brain Res 1987, 424(1):193-198.

338. Xu Y, Kalyanaraman B. Synthesis and ESR studies of a novel cyclic nitrone spin trap attached to a phosphonium group-a suitable trap for mitochondria-generated ROS? Free Radic Res 2007, 41(1):1-7.

339. Yagi-Utsumi M, Yamaguchi Y, Boonsri P, Iguchi T, Okemoto K, Natori S, Kato K. Stable isotope-assisted NMR characterization of interaction between lipid A and sarcotoxin IA, acecropin-type antibacterial peptide. Biochem Biophys Res Commun 2013, 431(2):136-140.

340. Yamato M, Egashira T, Utsumi H. Application of in vivo ESR spectroscopy to measurement of cerebrovascular ROS generation in stroke. Free Radic Biol Med 2003, 35(12):1619-1631. 
341. Yan W, Lee H, Deutsch EW, Lazaro CA, Tang W, Chen E, Fausto N, Katze MG, Aebersold R. A dataset of human liver proteins identified by protein profiling via isotopecoded affinity tag (ICAT) and tandem mass spectrometry. Mol Cell Proteomics 2004, 3(10):1039-1041.

342. Yang FY, Guo BQ, Wang DH. $\mathrm{Mg}^{2+}$-mediated change in lipid fluidity enhances the reconstituted H+-ATPase activity. Sci Sin B 1983, 26(10):1045-1056.

343. Yang FY, Huang YG, Zhang XF, Guo BQ. Magnesium mediated change in physical state of phospholipid modulates membrane ATPase activity. Magn Res 1988, 1(1-2):1321.

344. Yang L, Mester Z, Zhou L, Gao S, Sturgeon RE, Meija J. Observations of large mass-independent fractionation occurring in MC-ICPMS: implications for determination of accurate isotope amount ratios. Anal Chem 2011, 83(23):8999-9004.

345. Ye Y, Muller JG, Luo W, Mayne CL, Shallop AJ, Jones RA, Burrows CJ. Formation of ${ }^{13} \mathrm{C}$-, ${ }^{15} \mathrm{~N}$-, and ${ }^{18} \mathrm{O}$-labeled guanidinohydantoin from guanosine oxidation with singletoxygen. Implications for structure and mechanism. J Am Chem Soc 2003, 125(46):1392613927.

346. Yu W, Liu J, Colangelo C, Gulcicek E, Zhao H. A new protocol of analyzing isotope-coded affinity tag data from high-resolution LC-MS spectrometry. Comput Biol Chem 2007, 31(3):215-221.

347. Zhang XF, Yang FY. Further study on the role of $\mathrm{Mg}^{2+}$ in lipid-protein interaction in reconstituted porcine heart mitochondrial $\mathrm{H}^{+}$-ATPase. Biochim Biophys Acta 1989, 976(1):53-62.

348. Zhang DS, Piazza V, Perrin BJ, Rzadzinska AK, Poczatek JC, Wang M, Prosser HM, Ervasti JM, Corey DP, Lechene CP. Multi-isotope imaging mass spectrometry reveals slow protein turnover in hair-cell stereocilia. Nature 2012, 481(7382):520-524.

349. Zhang J, Katta V. Identification of Asp isomerization in proteins by ${ }^{18}$ O labeling and tandem mass spectrometry. Methods Mol Biol 2012 899:365-377.

350. Zhang S, You J, Ning S, Song C, Suo YR. Analysis of estrogenic compounds in environmental and biological samples by liquid chromatography-tandem mass spectrometry with stable isotope-coded ionization-enhancing reagent. J Chromatogr A, 2013, 1280:84-91.

351. Zhong H, Dong L, Dong Q, Ke C, Fu J, Wang X, Liu C, Dai L. Quantitative analysis of aberrant fatty acid composition of zebrafish hepatic lipids induced by organochlorine pesticide using stable isotope-coded transmethylation and gas chromatographymass spectrometry. Anal Bioanal Chem 2012, 404(1):207-216.

352. Zhou R, Guo K, Li L. 5-Diethylamino-naphthalene-1-sulfonyl chloride (DensCl): a novel triplex isotope labeling reagent for quantitative metabolome analysis by liquid chromatography mass spectrometry. Anal Chem 2013, 85(23):11532-11539.

353. Zimmermann JL, Schneider B, Morlet S, Amano T, Sigalat C. The role of the $\mathrm{Mg}^{2+}$ cation in ATP synthase studied by electron paramagnetic resonance using $\mathrm{VO}^{2+}$ and $\mathrm{Mn}^{2+}$ paramagnetic probes. Spectrochim Acta A Mol Biomol Spectrosc 2000, 56A(2):285-299. 